\title{
Technical Evaluation, Testing, and Validation of the Usability of Electronic Health Records: Empirically Based Use Cases for Validating Safety- Enhanced Usability and Guidelines for Standardization
}

\author{
Svetlana Z. Lowry \\ Mala Ramaiah \\ Sheryl Taylor \\ Emily S. Patterson \\ Sandra Spickard Prettyman \\ Debora Simmons \\ David Brick \\ Paul Latkany \\ Michael C. Gibbons
}

This publication is available free of charge from: http://dx.doi.org/10.6028/NIST.IR.7804-1

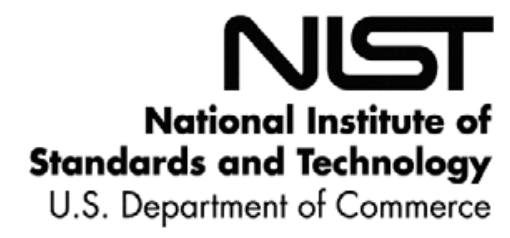


NISTIR 7804-1

\title{
Technical Evaluation, Testing, and Validation of the Usability of Electronic Health Records: Empirically Based Use Cases for Validating Safety-Enhanced Usability and Guidelines for Standardization
}

\author{
Svetlana Z. Lowry \\ Mala Ramaiah \\ Information Access Division \\ Information Technology Laboratory \\ Sheryl Taylor \\ Software and Systems Division \\ Information Technology Laboratory \\ Emily S. Patterson \\ The Ohio State University \\ Columbus, $\mathrm{OH}$ \\ Sandra Spickard Prettyman \\ Akron University \\ Akron, $\mathrm{OH}$ \\ Debora Simmons \\ St. Luke's Health System \\ Houston, TX \\ David Brick \\ NYU Langone Medical Center \\ New York, NY \\ Paul Latkany \\ New York Eye and Ear Infirmary \\ New York, NY \\ Michael C. Gibbons \\ The Johns Hopkins University \\ Baltimore, $M D$
}

This publication is available free of charge from:

http://dx.doi.org/10.6028/NIST.IR.7804-1

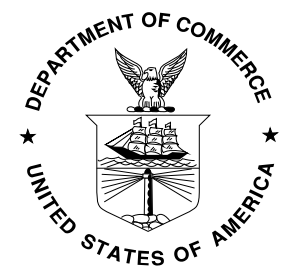

October 07, 2015

U.S. Department of Commerce

Penny Pritzker, Secretary

National Institute of Standards and Technology

Willie May, Acting Under Secretary of Commerce for Standards and Technology and Acting Director 


\section{Acknowledgments}

The authors gratefully acknowledge the intellectual contributions from the following:

- Mary Theofanos, M.S., Human Factors Scientist, National Institute of Standards and Technology

- Brian Stanton, M.S., Cognitive Scientist, National Institute of Standards and Technology

- Kristen Greene, Ph.D., Cognitive Scientist, National Institute of Standards and Technology

- David R. Hunt, M.D., Medical Director, Patient Safety \& Health IT Adoption at Office of the National Coordinator, Office of the Chief Medical Officer

- Teresa Zayas-Caban, Ph.D., Special Assistant to the Deputy National Coordinator , Office of the National Coordinator

- Ellen V Makar, M.S.N., R.N.-B.C., C.C.M., C.P.H.I.M.S., C.E.N.P., US Dept. of Health and Human Services, Agency for Healthcare Research and Quality, Center for Evidence and Practice Improvement

- Michael L. Hodgkins, M.D., M.P.H., Chief Medical Information Officer, American Medical Association

- Tejal Gandhi, M.D., M.P.H., CPPS, President, National Patient Safety Foundation

- Limor Hochberg, M.S., Human Factors Specialist, Life \& Health, UL LLC, Wiklund R\&D

- Kelly Cochran, M.S., R.N., Policy Advisor, Health Information Technology, Department of Health Policy, American Nurses Association

- Mary D. Patterson, M.D., M.Ed., Associate Vice Chair, Medical Education Research in Simulation, Director of Children's Academy of Pediatric Educators, Children's National Medical Center

- Janey Barnes, Ph.D., Human Factors Specialist, User-View, Inc.

- Susan Harkness Regli, Ph.D., Human Factors Scientist, University of Pennsylvania Health System

- Ross Teague, Ph.D., Senior Manager of User Experience, Allscripts Healthcare Solutions, Inc.

- Hardeep Singh, M.D., MPH, Chief, Health Policy, Quality and Informatics Program, Houston Veterans Affairs Health Services Research Center for Innovations

- John Ritter, HL7 EHR Work Group co-chair; PHR Work Group co-facilitator; EHR System Usability Work Group co-facilitator HL7 International Mentoring Committee co-chair ISO TC/215 U.S. Technical Advisory Group member Western Pennsylvania HIMSS Board of Director member

- Thomas Elmquist, M.D., Cardiologist, New York Cardiovascular Associates

- Todd C. Hughes, Ph.D., Chief Technology Officer, Next Century Corporation

- Theresa Cullen, M.D., Chief Medical Information Officer, Veterans Health Administration (VHA)

- Jorge A. Ferrer M.D., M.B.A., Biomedical Informatician, VHA OIA Health Informatics, Adjunct Assistant Professor, UTHealth School of Biomedical Informatics

- Jan Horsky, Ph.D., Senior Research Scientist, Brigham and Women's Hospital, Division of General Internal Medicine and Primary care; Harvard Medical School 
In addition, the authors appreciate the access to the data collected under NIST contract number SB134110CN0107 (UL-Wiklund) and the many instructive contributions from a broad spectrum of stakeholders on the draft document during an invited stakeholder meeting held at the National Institute of Standards and Technology on September 28, 2015, as well as peer reviewers for their constructive feedback on prior drafts of the document.

\section{DISCLAIMER}

Certain commercial entities, equipment, or material may be identified in this document in order to describe a concept adequately. Such identification is not intended to imply recommendation or endorsement by the National Institute of Standards and Technology, nor is it intended to imply that these entities, materials, or equipment are necessarily the best available for the purpose. 


\section{Table of Contents}

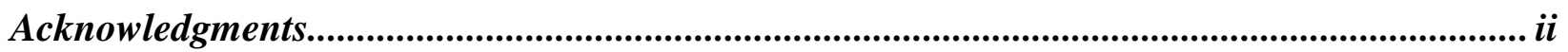

Table of Contents ...............................................................................................................................

Executive Summary .......................................................................................................................................

1 Introduction: Enhancing Safety with Empirically Derived Guidelines for Standardization .. 1

2 Methods for Identifying Critical Use Risk Areas................................................................................. 2

3 Major Findings from Data Analysis ............................................................................................ 9

4 Methods for Generating Guidelines and Validation Use Cases................................................. 15

5 Use Cases for Validation Testing to Ensure Safety-Enhanced Design .... Error! Bookmark not defined.

6 Empirically Based Human Factors Guidance for Safety-Enhanced Design of Health Information Technology .............................................................................................................. 36

7 Conclusions ........................................................................................................................................ 41

8 References .................................................................................................................................................. 43 


\section{Executive Summary}

This document provides the empirical rationale for critical patient safety-related usability guidelines for standardization. As well as requirements for validation testing to ensure safety-enhanced design. These standardization guidelines are targeted at eliminating 'never events' and associated patient harm by proactively addressing and mitigating the root causes of use errors from EHR design and implementation elements, as characterized in our framework on the relationship between usability and patient safety (NISTIR 7804).

Requirements for validation testing are instantiated through realistic use cases that can be applied during design and evaluation of Electronic Health Record (EHR) systems and for user performance testing. The ultimate goal is to drive and empower effective and safe human performance in the use of EHRs. The objective of this research is to enhance safety-related usability with empirically derived guidance in order to improve the effectiveness and efficiency of EHRs by eliminating or reducing the most critical and likely causes of patient harm from mistakes and errors in interaction.

This research drew upon five different methods of empirical human performance data collection, using crosscutting analytic methods, with a diverse set of analysts from different disciplines, backgrounds, and perspectives. Researchers applied this mixed method approach in order to capture user expectations, knowledge, and outcomes regarding EHRs. Multiple forms of data were collected from a variety of user types, allowing for a comprehensive view of EHRs. Two large, multi-hospital healthcare systems in the U.S. served as sites for most of the data collection, including observations and interviews. Data collection included: 1) an online survey; 2) site observations; 3) follow-up interviews with users; 4) usability testing of five different EHRs; and 5) expert reviews of the same EHRs. Research results demonstrate strong congruence among the data, methods, and the analysts.

Human factors guidelines for standardization, which were explicitly derived from the empirical evidence obtained through field data collection, are provided to improve the safety-related usability of EHRs in each of the following three critical use risk areas:

1) Consistently display information critical to patient identification in a reserved area to avoid wrong patient errors,

2) Provide cues to reduce the risk of entering information and writing orders in the wrong patient's chart, and

3) Support efficient and easy identification of inaccurate, outdated, or inappropriate items in lists of grouped information by having information presented clearly and in a well-organized manner.

Two use cases, one for the inpatient setting and one for the outpatient setting, are provided for validation with summative usability testing. Employing use cases oriented to empirically- derived usability challenges is intended to validate that potential patient safety risks are proactively mitigated in the tested EHRs. These use cases may also prove useful for organizations for adapting aspects of the design during implementation and optimization processes to protect against inadvertently introducing new risks to patients. 
Ultimately, this research demonstrates that patient safety is negatively affected when critical safety tasks are performed with the support of poorly designed EHRs. As a result, mistakes and errors frequently occur; with end users becoming frustrated and unwilling to trust the systems they are given and therefore are more likely to rely on potentially unsafe workarounds. 


\section{Introduction: Enhancing Safety with Empirically Derived Guidelines for Standardization}

This document outlines the empirical rationale for critical patient safety requirements instantiated in use cases that can be used during the design, evaluation, and user performance testing of EHR systems. Electronic Health Records (EHRs) offer great promise for improving healthcare processes and outcomes, including increased patient safety. Emerging evidence suggests that the use of health information technology (HIT) may help address significant challenges related to healthcare delivery and patient outcomes. ${ }^{1}$ For example, three reports suggest that the use of HIT may improve healthcare outcomes ${ }^{2}$ and reduce patient mortality. ${ }^{3}$ In addition, the use of HIT is a key component of a national strategy to improve healthcare quality and patient safety. ${ }^{4}$ Given the estimate that one in three patients will potentially be harmed during a hospitalization, ${ }^{5}$ the role for EHRs to improve patient safety may be significant.

On the other hand, studies found that patient mortality unexpectedly increased following the introduction of an EHR in a pediatric hospital ${ }^{6}$ and that an order-entry system contributed to a severe medication overdose. ${ }^{7}$ Therefore, empirically-derived guidelines for standardization are needed to foster enhanced ability to protect patients from inadvertent harm from EHRs. As with any HIT, EHR usability problems that can adversely impact patient safety can be assessed, understood and managed. Data collected through multiple methods can increase the validity of findings regarding the magnitude of risk to patients.

The ultimate objective of enhancing safety with empirically derived guidelines for standardization is to improve the effectiveness and efficiency of EHRs, and thus reduce the opportunity for patient harm from mistakes and errors. Failing to have effective and efficient EHRs could result in clinical users 'extensive workarounds that can directly and negatively impact patient safety. 


\section{Methods for Identifying Critical Use Risk Areas}

Researchers applied a multiple research methods approach in order to triangulate user interactions, experience and dispositions of common encounters with EHRs. Multiple forms of data were collected from a variety of user types allowing for a comprehensive view of EHRs. Data include: 1) an online survey; 2) site observations at two geographical locations; 3) interviews with users at these two locations; 4) usability tests with five different EHRs; 5) and expert reviews of the same EHRs. A team of researchers with expertise and extensive experience in research methods executed the effort, aided by three additional researchers, including clinical experts and human factors experts.

\section{Data Collection}

Data for this study were collected via NIST Contract Number SB134110CN0107 (UL-Wiklund). Data collection commenced in September 2010 and concluded in May 2015. Two large, multihospital healthcare systems in the U.S. served as sites for much of the data collection, including the observations and interviews. Two weeks of observations and 40 interviews occurred in a variety of care settings and with different types of user groups who routinely used EHRs. There was extensive effort of unobtrusive 'in situ' observation and follow-up interviews in these locations. A total of 86 EHR users were interviewed and observed, including 49 medical assistants and administrative staff members. Verbatim transcriptions of interviews and researcher field notes provided accurate and reliable data for the analysis. There were over 300 pages of interview transcripts and 336 observation notations.

In addition, five EHR developers volunteered their EHRs for usability testing. There were a total of 15 two-hour test sessions per EHR, resulting in a total of 63 participants, including 31 providers (physicians, nurse practitioners, and physician assistants), 21 nurses, and 11 medical assistants. Several two-person teams, each including a test administrator and a data analyst (i.e., data logger), conducted the usability tests. All test sessions took place in usability test facilities that included a test room and adjacent observation room. All test sessions were video recorded. Test data included use errors, “close calls”, difficulties, anecdotal comments about EHR interactions and quantitative ratings of the EHR according to a scoring system focused on safety-related usability which was developed as part of NIST contract SB134110CN0107. This scoring system, using responses as a 5point Likert scale from 1 = strongly disagree to 5 = strongly agree, was comprised of these statements:

- $\quad$ The EHR uses familiar terms, symbols, and units.

- The EHR makes important information stand out.

- The EHR's workflows match my expectations.

- The EHR makes it easy to detect and correct mistakes.

- The EHR gives me a comprehensive view of a patient's health.

- The EHR will prevent harmful mistakes.

- The EHR makes it easy to share information with other healthcare professionals.

- I can use the EHR effectively while working under pressure.

- The EHR is easy to learn to use.

- I am confident that I can use the EHR to perform tasks correctly. 
At the same time, six usability, informatics, and human factors experts independently reviewed the same five EHRs in order to identify interface strengths and weaknesses of each. Of 665 strengths and weaknesses identified overall, 60 weaknesses were identified by a human factors expert to potentially have patient safety implications. Examples include having the patient name displayed on the lower right corner of the screen, unlabeled graph axes, values displayed without accompanying units (e.g., 225 without lbs), a value of 11 years and 11 months plotted as 11 years on the $\mathrm{X}$ axis of a graph, not allowing physician users to edit or cancel an order after submission, and requiring one tab to be open when writing an order and a different tab to be open when submitting a medication order.

Finally, a single academic medical center participated in an online survey, with approximately 2,500 surveys sent to clinicians and administrators from 19 different departments/units. There were 559 responses, of which 339 responses were complete (13.5\% response rate). Nurses and physician providers were the largest categories of user types who responded. There were 21 questions on the survey, including two open-ended questions: 1) What EHR characteristics make it particularly easy to use? and 2) What EHR characteristics make it particularly difficult to use?

\section{Data Analysis}

Quantitative and quantitative data set/analysis are described in NIST GCR 15-996 “Technical Basis for User Interface Design of Health IT”. ${ }^{1}$ Consecutive qualitative analysis of the interview and observation data began with multiple readings of the full data set by the lead researcher and one of the research analysts. Each of these two researchers coded a subset of the qualitative data in order to begin a conscious and collaborative process of peer debriefing related to coding agreement. The goal was to insure that the researchers' use of codes and their application to segments of text was consistent; "the more coders (using the same codebook) agree on the coding of a text, the more we can consider the codebook a reliable instrument" ${ }^{8}$ (page 310 ). This process is recommended in qualitative research in order to establish the "credibility" or "truth value" of the findings. ${ }^{9,10}$ During peer debriefing sessions, researchers operationalized all codes and reviewed the data linked to various codes. This process occurred regularly during the multiple coding phases, allowing for continual reflection on and refinement of the codes and their application to the data.

Both researchers continued to read through the interview and observation data, creating tentative labels for chunks of data that summarized what was emerging from the data. This was the open coding process ${ }^{11}$ or first cycle coding ${ }^{12}$. During this coding cycle, approximately 60 different codes were used, with 30 of those occurring consistently across the data. While many of the remaining 30 codes only occurred once or twice, several of these represented critical cases where the data seemed important enough (for example, those related specifically to patient safety). These critical case codes became part of the code list that was used in the next coding cycle.

Once saturation occurred in the open coding process, the place where no new properties or dimensions emerged from the coding process, we moved on to axial coding. Axial, or second cycle $^{13}$, coding provided a means to identify the relationships and connections amongst the open codes. This allowed for the development of conceptual categories that link the codes and associated data. Richards and Morse ${ }^{14}$ argue that coding "leads you from the data to the idea, and from the idea

\footnotetext{
${ }^{1}$ Available at http://nvlpubs.nist.gov/nistpubs/gcr/2015/NIST.GCR.15-996.pdf. Accessed September 28, 2015.
} 
to all the data pertaining to that idea” (page 137). During this phase of the analysis, two top-level categories of codes: 1) issues related to input and/or handling of data and information and 2) issues related to understanding and use of the EHRs were identified.

Finally, selective coding identified core variables and emergent themes that occurred across the data set. ${ }^{15}$ Each researcher developed and shared memos and models about ongoing interpretations of the data as a means to identify conceptual categories and move toward the development of emergent themes for critical use risk areas that allowed researchers to predict patterns "of what may be observed and what may happen in similar present and future contexts." ${ }^{6}$ Here, three major critical use risk areas emerged as our ultimate findings: Identification of information, Consistency of information, and Integrity of information.

At the same time, the lead researcher and the data analyst coded the usability test data. The same conceptual categories and emergent themes developed in this data as in the interview and observation data. Similarly, the lead researcher reviewed the survey data for overlap between this and other data sources. Again, similar ideas surfaced across the data sets. Finally, the human factors researcher examined expert reviews to discern patterns across reviews related to the issues under consideration, specifically the relationship between the EHRs and patient safety. The lead researcher used the findings to map back to the other data forms. The conceptual categories and emergent themes are represented across the data sets, demonstrating the strength of the findings.

\section{Examples of Codes, Categories, and Critical Use Risk Areas}

In qualitative research, a code "symbolically assigns a summative, salient, essence-capturing, and/or evocative attribute for a portion of language-based or visual data." ${ }^{7}$ Coding is a cyclical act that serves as an intermediary between data collection and data analysis. Saldaña ${ }^{18}$ argues that qualitative codes capture essential elements of the data, and when those elements form clusters they can "facilitate the development of categories and thus analysis of their connections" (p. 8). Codes are rooted in the data, but as coding and analysis continue, codes and categories become more refined, and often more conceptual and abstract. A further shift is evidenced "when the major categories are compared with each other and consolidated in various ways, you begin to transcend the "reality" of your data and progress toward the thematic, conceptual, and theoretical" (p. 12). Below are excerpts of particular pieces of interview data and the codes applied to them, followed by how these led to broader categories of analysis and later to emergent themes that ran across data sets. It should be noted that the excerpts below are exemplars to demonstrate how data were coded, however many more data segments were coded with the same codes. Many codes resurfaced multiple times in the same interview and most occurred across all interviews. 


\section{Table 1. Examples of individual data excerpts and codes}

\begin{tabular}{|c|c|}
\hline DATA & CODE(S) \\
\hline $\begin{array}{l}\text { "Sometimes, I might issue a rapid strep test and then save the note as a draft so that I have to go back in at end of day to save as } \\
\text { final based on strep test results. I might need to edit [the] plan, and then I also give patient both plans of action. [The] system will } \\
\text { send me a message reminding me to save the drafts, but you have to be paying attention, and there are a lot of things to pay } \\
\text { attention to". }\end{array}$ & $\begin{array}{l}\text { DRAFT VS. FINAL; } \\
\text { RELIANCE ON } \\
\text { MEMORY }\end{array}$ \\
\hline $\begin{array}{l}\text { "Running through a list of med[ication]s can take quite a bit of time. When a patient gets admitted to the hospital and discharged, } \\
\text { the med[ication] list changes. To me, there is a right way to write a prescription, so that we can communicate it. When [a] patient } \\
\text { gets discharged, sometimes pertinent medic[ations] can get deleted, and the format changes. When they get discharged, the units } \\
\text { might be off, the units might say mg, but the mom tells me she gives mL. The mom won't know what mg means. If [the] patient } \\
\text { come[s] from [the] hospital, it might take me a half hour to update it". }\end{array}$ & $\begin{array}{l}\text { MEDICATION LISTS } \\
\text { CHANGE; } \\
\text { MEDICATIONS } \\
\text { DELETED; } \\
\text { UNITS OF MEASURE } \\
\text { CHANGE }\end{array}$ \\
\hline $\begin{array}{l}\text { "I think you could send a message on the wrong patient. Let's say that the mom called and the child has breathing difficulty and } \\
\text { you are accidentally in [the] wrong record. It's not the information that gets into the wrong patient, it's knowing what patient the } \\
\text { information belonged to. Sometimes, [the] wrong vaccine gets recorded. I notice something might be wrong, the age is wrong, I } \\
\text { can get someone to go in and delete [the] vaccine, but then we are missing the information on [the] proper patient's record. We } \\
\text { may be able to identify later when that patient comes in, but if we can't find it, the patient gets an extra vaccine". }\end{array}$ & $\begin{array}{l}\text { WRONG } \\
\text { PATIENT/CHART; } \\
\text { VACCINE ERRORS }\end{array}$ \\
\hline $\begin{array}{l}\text { "My patient list is incorrect. It is not a complete patient list and I don’t know why. Sometime over the past } 6 \text { to } 8 \text { months } 2 / 3 \text { of } \\
\text { my list got purged. I have to remember the patients’ names and search through [the current EHR] to find...It is very frustrating } \\
\text { because I have no idea why it happened. Suddenly, one day I had 3,200 patients on my list and the next day I had 700. It doesn’t } \\
\text { make any sense. Every day the system does not feel firm or complete”. }\end{array}$ & $\begin{array}{l}\text { WRONG PATIENT } \\
\text { LISTS; } \\
\text { FRUSTRATION }\end{array}$ \\
\hline $\begin{array}{l}\text { "A patient going from outpatient to inpatient or vice versa. Often times the medications are not addressed appropriately at those } \\
\text { transition periods. Often what's in the discharge summary is not what's in the medication list in the patient summary and so often } \\
\text { times it's confusing to figure out. The person discharging the person is not diligent in updating the medications and I don't know } \\
\text { if this happens, but it seems to be that somehow the inpatient medications and discharge summary medications should all auto- } \\
\text { populate". }\end{array}$ & $\begin{array}{l}\text { WRONG/DISCREPANT } \\
\text { MEDICATION LIST; } \\
\text { NEED FOR AUTO- } \\
\text { POPULATION }\end{array}$ \\
\hline $\begin{array}{l}\text { "No checks and balances for diagnoses in patient summary. Say a patient is seen by one provider and provider goes in patient } \\
\text { summary, sees that they have [a] scar on [the] chest so must have had CAD [Coronary Artery Disease] and surgery. If I see the } \\
\text { patient and change the summary all around and correct it, say they never had a heart attack, say I update that, if that patient goes to } \\
\text { see someone else... there's no accountability. Anyone can change anyone else's patient summary. Patient could come back to me } \\
\text { after seeing } 3 \text { other people, no longer looks like what I spent an hour updating. I can go back and look at my patient summary and } \\
\text { try to paste it forward. But [there] are oftentimes disease-specific information that other services might delete, and they delete it, } \\
\text { but it's actually the record. Can be frustrating and lead to errors". }\end{array}$ & $\begin{array}{l}\text { CHANGES MADE TO } \\
\text { NOTES; } \\
\text { NO } \\
\text { ACCOUNTABILITY; } \\
\text { DELETED } \\
\text { INFORMATION; } \\
\text { FRUSTRATION; } \\
\text { ERRORS }\end{array}$ \\
\hline
\end{tabular}


Table 1. Examples of individual data excerpts and codes (Cont.)

\begin{tabular}{|c|c|}
\hline DATA & CODE(S) \\
\hline $\begin{array}{l}\text { "Patients can receive } 2 \text { doses of medication because of how read-only scripts are handled in the system, e.g., [for example] read- } \\
\text { only means that there is no physical order, the pharmacy can view and dispense the medication, but with a read-only order there is } \\
\text { no way to scan or manually document that the patient received the medication. Order could be filled and given twice. EHR user } \\
\text { has to complete 8-9 clicks to get to a more detailed view to see comments if the script has been given to the patient". }\end{array}$ & $\begin{array}{l}\text { WRONG } \\
\text { MEDICATION OR } \\
\text { DOSE; } \\
\text { DIFFICULTY OF USE } \\
(8-9 \text { CLICKS) }\end{array}$ \\
\hline $\begin{array}{l}\text { "I've seen this EHR [at this hospital] go from a reporting mechanism to a data entry mechanism, to the point where it becomes a } \\
\text { file cabinet that you shove paper into. I guess if you control it [data entry], you know where things are. But, if my assistant or my } \\
\text { colleagues begin to use my file cabinet, pretty soon I'm not going to know what's in there. I might be able to find a paper I filed } 6 \\
\text { months ago, but it's a needle in a haystack. Indexing is not standardized. It's difficult to figure out where to start. [This is] what } \\
\text { am I worried about”. }\end{array}$ & $\begin{array}{l}\text { "FILE CABINET"; } \\
\text { OUT OF CONTROL; } \\
\text { “NEEDLE IN } \\
\text { HAYSTACK"; } \\
\text { NEED FOR } \\
\text { STANDARDIZATION }\end{array}$ \\
\hline $\begin{array}{l}\text { "The list in the EHR is populated by multiple individuals. It's a mish mash. Stuffing information in drawer, I may own a section } \\
\text { of that, not [the] entire piece”. }\end{array}$ & $\begin{array}{l}\text { "MISH MASH” OF } \\
\text { INFORMATION } \\
\text { USED BY DIFFERENT } \\
\text { INDIVIDUALS; } \\
\text { POSSBILITY FOR } \\
\text { CHANGES/ERRORS }\end{array}$ \\
\hline $\begin{array}{l}\text { "Let's say the patient is on Coumadin and then an internist gives an antibiotic. If [I] get prompted to refill the Coumadin, [then] I } \\
\text { get prompted that [the] patient is on an antibiotic and it tells me to consider decreasing [the] dose. That's a robust decision support } \\
\text { piece that only works with providers in this EHR system [at this hospital]. It only works if I'm here and I see that you prescribed } \\
\text { that. It [EHR] doesn't reflect the antibiotic received at [the] walk-in clinic". }\end{array}$ & $\begin{array}{l}\text { WRONG } \\
\text { MEDICATION OR } \\
\text { DOSE; } \\
\text { MEDICATION } \\
\text { INTERACTIONS }\end{array}$ \\
\hline $\begin{array}{l}\text { "Omitted information. It would be through omission, or you chart on the wrong kid. That would be human error. Safety thing is } \\
\text { when patient was omitted and all information was left out. The log in/log out thing is a huge pain in the butt. If I'm working at the } \\
\text { desk and someone says "Hey,” I run. If User Y comes back and was working at that spot, he might sit down and chart on me [the } \\
\text { chart I was working on before leaving]”. }\end{array}$ & $\begin{array}{l}\text { OMITTED } \\
\text { INFORMATION; } \\
\text { WRONG } \\
\text { PATIENT/CHART }\end{array}$ \\
\hline
\end{tabular}


As coding continued, codes seemed to cluster into two major conceptual categories: 1) input and handling issues and 2) understanding and use issues. For example, "Draft vs. Final" seemed to be an input issue, as did "Changes Made to Notes" and "File Cabinet." These codes were connected by their relationship to the ways in which data made its way (or not) into the system. Likewise, data related to "Medications Change" or "Wrong Patient" clustered around the ways in which participants understood and used the EHRs. Sometimes chunks of data related to both categories, as in the case of "Wrong Patient/Chart." For example, P43 above noted that someone might be working on a chart, need to leave for another task, and then someone else would begin to work on it, thinking it was a different chart. This was an input issue (in that data was input into the wrong chart), but also a use issue in that it was often difficult to discern which chart one was in at a given time. The second cycle of coding allowed analysts to revisit previously coded data and cluster it around these two conceptual categories. During this process, analysts noted that both categories produced issues related to Identification of Information, Consistency of Information, and Integrity of Information. These critical use risk areas pulled together a variety of related codes that were united conceptually. For example, Identification of Information represented those instances in the data where a piece of information was unable to be identified, was misidentified, or was difficult to identify (this could be a patient name, a medication, a chart number, or whether something was a draft versus a final entry). Consistency of Information related to where and how information was presented, and often referred to a lack of standardization in where and how information was presented as in where and how the patient name was presented or a medication was entered. Finally, Integrity of Information encompassed those codes where the accuracy of information was difficult to discern, sometimes due to information being changed, being deleted, or not being entered.

Once coding of observation and interview data was complete, researchers looked across data sets for congruence of analysis. Many of the codes generated in the analysis of observation and interview data also emerged in the usability tests and expert reviews. For example, location of patient name, unlabeled graph axes, values displayed without accompanying units, not allowing physician users to edit or cancel an order after submission, and requiring one tab to be open when writing a medication order and a different tab to be open when submitting a medication order. Survey data also corroborated the coding structure and the subsequent development of conceptual categories and themes. Identification of information, Consistency of information, and Integrity of information cut across the data as major areas of use risk.

\section{Trustworthiness}

According to Lincoln and Guba ${ }^{9}$, trustworthiness involves establishing credibility, transferability, dependability, and confirmability. Triangulation is one way to insure a comprehensive, well developed, and systematic analysis that provides for credibility in the process and the findings. ${ }^{19,20}$ Triangulation can take many forms, including triangulation of methods (using multiple methods for both data collection and analysis), triangulation of sources (from within the same method-for example having Medical Assistants, Nurses, and Providers as participants in the interviews and usability tests), and triangulation of analysts (to provide for differing analytic lenses and perspectives). Researchers in this project used all three types of triangulation to provide a more robust process and insure a more holistic and comprehensive

picture of the findings. Mays and Pope ${ }^{21}$ suggest additional mechanisms for enhancing the 
trustworthiness of a study, including respondent validation, where study participants are asked to respond to and assess the researchers' interpretations. While traditional respondent validation (or member checking as it is also known) was not utilized here, researchers held a debriefing session with people from a range of roles and positions, including nurses, doctors, and human factors experts in order to obtain feedback regarding the analysis, interpretation, and findings. Peer debriefing and respondent validation provided additional credibility for the study. ${ }^{9}$

The use of "thick description"9 and the voices of participants allow for greater transferability, or the ability of readers to determine for themselves whether or not the results generalize to their own situations. The presentation of extensive quotes and the detailed description of the coding and analysis process in this report allow for such transferability. Dependability refers to how likely it is that the findings would be consistent if the study were done again with a similar set of participants in a similar context. Dependability can be achieved through the use of an external audit where researchers who were not involved in the project review the process and products of the research. In this study, the debriefing session with a variety of different experts offered a space for presentation and discussion of the research process and the findings. Confirmability provides a mechanism to determine if the conclusions, recommendations, and/or interpretations can be traced to their sources, insuring that the findings are a product of the study and not of researcher bias. An audit trail of the data and its processing allows for such confirmability. Mays and Pope $^{20}$ also argue that a clear presentation of the data collection and analysis methods provide for greater validity of the study. 


\section{$3 \quad$ Major Findings from Data Analysis}

This research examined the use of EHRs in different healthcare settings and with different types of users in order to gain a comprehensive view of the EHR impact. The objective is to improve their effectiveness and efficiency and thus reduce the likelihood of contributors to avoidable patient harm. We found three overarching themes representing critical areas of use risk, based upon a convergence of triangulated evidence from all of the data sources: identification of information, consistency of information and integrity of information. Within each overarching risk area are subcategories, characterized by prototypical statements and questions, and possible consequences, all rooted in the data. These are detailed in Table 2 below. Across all three of the risk areas and their related subcategories there arose several major issues related to patient safety: 1) the occurrence of unintended actions; 2) the likelihood of use errors; and 3) the high level of user frustration. The three areas and their related issues highlight a lack of effectiveness and efficiency related to EHRs. Ultimately, both the objective (actual observation and analysis of user performance) and subjective data demonstrate that these issues negatively affected patient safety during safety-critical tasks and times. For example, one participant discussed transition periods and how these often led to discrepancies in medication lists:

"So the patient going from outpatient to inpatient, or inpatient to outpatient. Often times the medications are not addressed appropriately at those transition periods, and so often times what's in the discharge summary is not what's in the medication list in the patient summary...And so often times it's confusing to figure out...The patient can end up being confused and taking either too much or too little, or the wrong medication combination. I, as the provider, on the other hand am unclear on what the patient is actually taking, and it leads to confusion when the patient calls and says, "I'm not responding to the treatment in the hospital. Then I have to go back and try to figure out, okay, are they not responding because they're not actually taking the right medicine, or something like that? And it also leads to confusion because the-- I had one patient who called our office from their hospital bed and said, "They're sending me home. I'm confused about my medication and nobody will talk to me." So not only was the documentation fraught with errors in instruction to the patient, they were just as confused as I was trying to figure out what they were going home with."

The data excerpt above demonstrates how the integrity of the information is compromised leading to incorrect dosages or medication combinations. Effectiveness is diminished as the likelihood for critical use errors increases and efficiency is affected since it will now take additional time to identify accurate information. This relationship was seen many times across the data set. Also related to integrity of information, a different participant noted how difficult it was to create an accurate patient summary:

"Actually, I was in with a patient. Gosh, was it Monday? I was trying to update the patient summary because that's essentially what I spend a lot of my time doing now with all new patients is I'm building all the patient summaries. Let's see if I can get to this patient summary. What ended up happening is, as I'm updating, I can hit update here, and when I'm updating, I can't see labs, I can't see anything else. I'm asking them, "When's your last tetanus? Have you had your diabetes screen checked?" And I can go up here to Actions, which I've now learned, and I can open up any one of these things in a different-- let's see if we can get the labs. I can open up labs, but what happened to me 
last time was that I was trying to open these up and it overwrote whatever I was doing here. It wouldn't let me save anything. It wouldn't let me get back to it to save it.”

Not being able to see lab results and other pertinent information, as well as not being able to save information as needed also reduce effectiveness and efficiency and create a situation where frustration and unintended actions are likely to occur.

In addition to the integrity of information, the consistency of information presentation and where to find it was a common issue. Two other participants articulated examples that many others corroborated related to this pattern:

"I've seen this EHR here at [hospital] go from a reporting mechanism to a data entry mechanism, to the point where it becomes a file cabinet that you shove paper into. I guess if you control it, you know where things are. But, if my assistant or my colleagues begin to use my file cabinet, pretty soon I'm not going to know what's in there. I might be able to find a paper I filed 6 months ago, but it's a needle in a haystack. Indexing is not standardized. It's difficult to figure out where to start...

Because if you read through it and you don't change it to make it up to date, and you don't bring forward the information that you've learned - they've got a new allergy, or they used a medicine that you gave last time and they have an adverse affect, or anything that they've told you that happened since you last used that note. If you don't bring it in to that note, and you don't record it, then not only have you created a safety concern for that patient, you've created a liability for yourself and for the institution."

Finally, the identification of information arose as a major issue, with many participants noting how difficult it was to easily locate and identify information and how easy it was to be in the wrong place. The data excerpt from a different participant below clearly illustrates the potential consequences of this issue:

"An example today: When I went in today to see a patient, there were two notes saved, one was a 3 year old draft that my nurse started, the other note was for a different patient. That's easily solved. I went in the room, noticed an incorrect note. I sent a message to the nurses. Asked them to delete it from record. But, in the meantime, one of my staff members went into room of 12 month old and couldn't find the record. I think you could send a message on the wrong patient. Let's say that the mom called and the child had breathing difficulty and you are accidentally in wrong record. It's not the information that gets into the wrong patient, it's knowing what patient the information belonged to. Sometimes, [the] wrong vaccine gets recorded. I notice something might be wrong, the age is wrong, I can get someone to go in and delete the vaccine, but then we are missing the information on the proper patient's record. We may be able to identify later when that patient comes in, but if we can't find it, the patient gets an extra vaccine."

It is important to note that the examples presented above serve as exemplars for a broad range of data found across the different methods that support the use risk areas and subcategories. These are by no means unique statements, but representative of the data as a whole. 
Table 2. Summary of Analytic Findings on Major Safety-Related Risk Areas and Possible Consequences

\begin{tabular}{|c|c|c|}
\hline Areas of Critical Use Risk & Subcategories & Possible Consequences \\
\hline \multirow{3}{*}{$\begin{array}{l}\text { Identification of Information } \\
\text { Am I in the right place and doing the right } \\
\text { thing? } \\
\text { - } \quad \text { For patient } \\
\text { - } \quad \text { For patient lists } \\
\text { - } \quad \text { For records } \\
\text { - } \quad \text { For medication/order }\end{array}$} & $\begin{array}{l}\text { Incorrect patient list } \\
\text { Who are these patients? } \\
\text { - Wrong treatment } \\
\text { - Wrong billing } \\
\text { - Wrong charting of information }\end{array}$ & $\begin{array}{l}\text { - Missed, omitted, delayed care } \\
\text { - Care or billing activity conducted on the wrong patient } \\
\text { - Have to pull up every patient chart } \\
\text { - Wrong medication ordered }\end{array}$ \\
\hline & $\begin{array}{l}\text { Passing/sharing information } \\
\text { What happens in the handoff? } \\
\text { Multiple EHRs used } \\
\text { What happens when EHRs don't coordinate? }\end{array}$ & $\begin{array}{l}\text { - Data/information are not recorded in EHR } \\
\text { - Misrecording or recording in wrong patient chart }\end{array}$ \\
\hline & $\begin{array}{l}\text { Fragmented information } \\
\text { Data are often fragmented and found in multiple } \\
\text { places }\end{array}$ & - Often no context for displayed information \\
\hline \multirow{4}{*}{$\begin{array}{l}\text { Consistency of Information } \\
\text { Why are things not listed and displayed in } \\
\text { standardized ways? } \\
\text { - For information } \\
\text { - For organization } \\
\text { - For format } \\
\text { - For different systems } \\
\text { - For draft vs. final versions } \\
\text { - For omissions and/or changes }\end{array}$} & $\begin{array}{l}\text { Misidentified patient/chart Where am I? } \\
\text { Record number is incorrect/Patient name is } \\
\text { misidentified. }\end{array}$ & $\begin{array}{l}\text { - Documentation/orders in wrong chart (often without } \\
\text { knowing it) }\end{array}$ \\
\hline & $\begin{array}{l}\text { Supplements used } \\
\text { Did I remember to transfer data to the EHR? } \\
\text { Paper, whiteboards frequently used (reliance on } \\
\text { memory) } \\
\text { Multiple EHRs used } \\
\text { Where do I find X on this EHR? } \\
\text { Functions and screens shift Where is my } \\
\text { information? }\end{array}$ & $\begin{array}{l}\text { - Cannot find information when needed in the EHR } \\
\text { - Reliance on memory for transfer of information/data }\end{array}$ \\
\hline & $\begin{array}{l}\text { Cannot find information } \\
\text { Where is my information? Am I in the right } \\
\text { place? } \\
\text { - On screen } \\
\text { - In file } \\
\text { - In EHR }\end{array}$ & $\begin{array}{l}\text { - Functions and screens shift } \\
\text { - Information found in different places (including record } \\
\text { number, patient name, medications prescribed, etc.) }\end{array}$ \\
\hline & $\begin{array}{l}\text { Standardization of where things are and what } \\
\text { they are } \\
\text { - Location and format of date } \\
\text { - Location of record number } \\
\text { - Location and format of name } \\
\text { - Format of amount (e.g., metric vs. US) } \\
\text { - Running list of current medications }\end{array}$ & $\begin{array}{l}\text { - Notation in wrong record } \\
\text { - Incorrect diagnosis or prescription } \\
\text { - Incorrect medication or order OR double vaccine }\end{array}$ \\
\hline
\end{tabular}


Table 2 Summary of Analytic Findings on Major Safety-Related Risk Areas and Possible Consequences (Cont.)

\begin{tabular}{|c|c|c|}
\hline Areas of Critical Use Risk & Subcategories & Possible Consequences \\
\hline \multirow[t]{4}{*}{$\begin{array}{l}\text { Integrity of Information } \\
\text { Why and how are things changed, deleted, } \\
\text { or omitted? } \\
\text { - Lack of control over changes in dates, } \\
\text { notes, units of measure } \\
\text { - Inability to know what information is } \\
\text { valid, relevant, and up to date }\end{array}$} & $\begin{array}{l}\text { Cannot figure out EHRs } \\
\text { How do I do this? } \\
\text { - Navigation is difficult } \\
\text { - Adding/deleting data is difficult } \\
\text { - Scrolling through long notes is time- } \\
\text { consuming }\end{array}$ & $\begin{array}{l}\text { - More likely to just use whiteboard/paper and not put } \\
\text { data in EHR, resulting in incomplete files/charts }\end{array}$ \\
\hline & $\begin{array}{l}\text { Draft vs. final version } \\
\text { Is this a draft or final version? Often forget to } \\
\text { finish a final version }\end{array}$ & $\begin{array}{l}\text { - Omissions of data/information; notation of incorrect } \\
\text { data/information } \\
\text { - What happens if change in patient condition in interim? }\end{array}$ \\
\hline & $\begin{array}{l}\text { Changes to note/chart } \\
\text { You changed what?!! } \\
\text { - Different user can change someone else's } \\
\text { note/input }\end{array}$ & $\begin{array}{l}\text { - Information lost } \\
\text { - Inaccurate and/or incomplete data and charts }\end{array}$ \\
\hline & $\begin{array}{l}\text { Common references not there } \\
\text { Why are height and weight not here? (and other } \\
\text { common data like vital signs) }\end{array}$ & $\begin{array}{l}\text { - Having to do things (input) multiple times or search } \\
\text { multiple places }\end{array}$ \\
\hline
\end{tabular}


Included in the two use cases are the following aspects, categorized by the areas of use risk that emerged from the data analysis and related to supporting evidence from the data analysis:

1) Critical Use Risk Area 1: Identification of Information

A) Accidentally transposing a patient's first and last name is easy to do when the names are both commonly used first names as well as possible last names (e.g., William John, John William). This increases the potential for making clinical orders or documenting in the wrong patient's chart due to the ease of inverting the names when searching for the chart, flipping the open chart to another person and mistakes can more easily occur when quickly scanning the name to confirm that the right chart is open. In the use cases for eligible providers and nurses, both William John and John William need to be included in the patient list.

B) Getting confused as to which chart is actively open for ordering medications and viewing information is challenging when there is an interruption in the midst of providing care for one patient in order to a high priority activity like look up the current medications for another patient in response to a phone call from the Emergency Department nurse for a patient who is not able to provide the information reliably.

C) Identifying an allergy to the common sugar substitute that is contained in the hospital's standard diabetic diet is challenging when relying upon clinical decision support alerts that are not designed to cover this scenario and/or have high false alarm rates.

D) Being interrupted while providing care to one patient can increase the risks of performing clinical actions or documenting information in the wrong patient chart.

2) Critical Use Risk Area 2: Consistency of Information

A) Having a primary care provider in the outpatient setting identify that the results of a diagnostic (MRI imaging) test are not available because they were not ordered as planned during a prior hospital stay can be challenging when results from within an organization and from other organizations are not displayed and sorted in a consistent fashion.

B) Managing and documenting an allergy to a preservative in intramuscular vaccines, thimerosal, is challenging because it differs from how the typical allergy to a medication is identified and alerted with clinical decision support and visualization paradigms Clinical decision support recommends ordering a vaccination for influenza despite the patient having an allergy to thimerosol, which is a preservative in the vaccination in the traditional injection delivery mechanism. A different form of the vaccine (that does not contain thimerosol) needs to be ordered to avoid an allergic reaction. 
C) Treating an infectious eye disease requires coordinating care with other specialized personnel, including infectious disease specialists and eye care specialists. It can be particularly challenging to coordinate care using "readonly" documentation. ${ }^{2}$

D) As soon as the nurse notices that the patient had a markedly pink irritated right eye on morning rounds, this information is critical to share quickly with other care providers in order to protect healthcare workers and other patients from infection by initiating and maintaining contact isolation precaution procedures. Sharing this information across transitions of care is similarly important.

3) Critical Use Risk Area 3: Integrity of Information

A) Managing medications requires reviewing medication lists which have discrepancies. $^{3}$

B) Reviewing the laboratory results of a blood test cannot be done during the primary care provider outpatient clinic visit with the patient because the results are not available for review.

C) An imaging test that was not completed in the acute care setting is not readily discoverable during the follow-up visit with the primary care provider as it was not completed in the primary care setting.

\footnotetext{
${ }^{2}$ Supporting evidence from the interview data: "Patients can receive 2 doses of medication because of how read-only scripts are handled in the system (e.g., read-only means that there is no physical order, the pharmacy can view and dispense the medication, but with a read-only order there is no way to scan or manually document that the patient received the medication. Order could be filled and given twice. EHR [Electronic Health Record] user has to complete 8-9 clicks to get to a more detailed view to see comments if the script has been given to the patient."

${ }^{3}$ Supporting evidence from the interview data: "I guess part of the biggest thing that we noticed, or that I see, is the transition periods. So the patient going from outpatient to inpatient, or inpatient to outpatient. Often times the medications are not addressed appropriately at those transition periods, and so often times what's in the discharge summary is not what's in the medication list in the patient summary... And so often times it's confusing to figure out. The person discharging the patient is not diligent in updating the medications. And I don't know if this happens but it seems to me somehow the inpatient medications and discharge summary medications should all populate the updated patient summary, but I don't know if that happens. And so if there's a discrepancy between what's in the patient summary med-list versus what's in the discharge summary, what can happen as a result of that? The patient can end up being confused and taking either too much or too little, or the wrong medication combination."
} 


\section{Methods for Generating Guidelines and Validation Use Cases}

Group of the human factors experts collaboratively mapped the findings from the data analysis to human factors terminology in order to relate the insights to what is known in the human factors field about contributors and barriers to successful, high reliability, and high reliance performance by experts in domains with high consequences for failure. This translation resulted in transforming the major findings into human factors issues and deficiencies, which enabled a more targeted search for existing solutions and standards on which to base the recommendations.

Subsequently, a team composed of a methodologist, clinical physicians, clinical nurses and human factors experts provided guidance on the generation of the recommendations and use case during a focused two-day working meeting. As a result of this meeting, the team generated safety-related usability technical guidance that draws upon existing human factors knowledge and is empirically grounded and prioritized on the basis of being repeatedly raised as important across five data collection methodologies. 


\section{Use Cases for Validation Testing to Ensure Safety-Enhanced Design}

The research findings provide empirical evidence about critically important usability issues that could potentially have negative impacts on patient safety for providing clinical care with the support of EHRs in both the inpatient and outpatient care settings. These issues provide the foundation for the creation of two challenging use cases intended for summative usability testing validation.

Healthcare is delivered within a system encompassing both ambulatory and inpatient settings. As such, designing support for clinical care in either or both of these settings is challenging even for an ordinary evolution of the care of a typical patient over a select time period in his or her life that requires continuity of care across multiple providers with dedicated roles.

In this section, we provide for evaluation purposes one use case for inpatient care and one use case for outpatient care. These two use cases are contextualized within an overarching narrative for a single patient with multiple care activities conducted by multiple types of care providers.

When recruiting study participants for the validation testing, there are two categories of care providers, 1) eligible professionals (medical doctors, nurse practitioners, or physician assistants) and 2) nurses (registered nurses, licensed practical nurses). By employing the same patient for the validation testing, it is possible to reuse demographic information and test data.

Overview of both use cases

The two use cases are situated within an integrated series of care encounters, consisting of:

1. An acute care hospital admission through the emergency department of a 45-bed community hospital for a number of concerning symptoms, including chest pain and a productive cough.

2. An outpatient visit with a primary care provider two years later, after a recent hospital admission for a possible stroke 
The use cases for evaluation cover selected aspects of the interactions dependent on the electronic health record. Initially, an overall scenario of the patient visit is provided. Next, the detailed steps involved by each user interacting with the EHR are enlisted. This is followed by a short description of the critical usability issues in the tasks of each of the user roles.

\section{Use Case 1: First Hospital Stay}

We discuss the use case in several parts. The complex scenario is likewise broken into relevant parts for better understanding and application. The scenario description is followed by the user tasks based on roles and the workflow per the scenario. Hence, the user may appear repeatedly as called by the events mentioned in the scenario. We associate the critical usability issues encountered in the performance of the tasks under each role as a subcategory.

\section{Scenario 1, Part I}

Mr. William John is a 65-year-old Hispanic male who presents to the Community General Hospital Emergency Department with complaints of severe chest pain, difficulty breathing and productive cough. Mr. John has a known history of Type 2 diabetes mellitus and hypercholesterolemia. His allergies include Thiomerisol and "pink sweetener". He is triaged and taken into the Emergency Department (ED). The ED nurse records the vital signs, which are within the normal limits except for lower oxygen saturation of $90 \%$ and an increased heart rate of 110 beats per minute, and informs the Emergency Physician. The Emergency Physician orders oxygen therapy per nasal cannula immediately, 12 lead EKG, serial troponin levels, chest X-ray, sputum gram stain now, CBC, continuous telemetry monitoring, finger stick blood glucose following the hospitals $\mathrm{s}$ diabetic protocol and continuation on his routine medications of a long acting insulin, regular insulin on a sliding scale, atorvastatin, vitamins and aspirin. He also starts the patient on azithromycin. He orders an 1800 calorie diabetic diet. The X-ray is confirmatory for pneumonia. The first troponin is negative. An initial 12 lead EKG reveals abnormal but nonsignificant ST segment changes. There is no cardiologist available and the internist will be the admitting physician.

\section{Scenario 1, Part II}

Mr. John is admitted to a Medical-Surgical (Med-Surg) unit under the care of the internist (admitting physician) for observation and treatment. Vital signs including $\mathrm{O}_{2}$ saturation had returned to normal. The resident physician informs the attending physician about the condition of the patient. The nurse collects the specimens and sends them to the lab in a labeled container. The attending physician, during rounds, changes the $\mathrm{O}_{2}$ therapy to "as needed" to maintain oxygen saturation above $96 \%$.

\section{Scenario 1 Part III}

Day 2: The nurse, when assessing the patient in the beginning of the shift, notices that the patient had a markedly pink itchy irritated right eye with a tearing sensation. The patient reported that 
he was on some eye drops in the distant past, but did not recall the name of the medication. The doctor who was then providing eye care moved out of town, and he does not remember the clinic's number.

The nurse had a high suspicion of viral conjunctivitis and puts the patient in contact isolation. She asked the physician if he wanted an Ophthalmology consult. Per the physician order, she requested the consultant Ophthalmologist. The ophthalmologist, during the consult, was able to elicit a history of being in contact with a family member that recently had "pink eyes". The patient was an occasional contact lens wearer but had none recently. The ophthalmologist established that the visual acuity, intraocular pressure, and ophthalmic exam were normal except for signs and symptoms consistent with viral conjunctivitis. The ophthalmologist ordered topical tetracaine $1 \%$ to be applied by the ophthalmologist to both eyes (and to have the bottles available in the patient's medication tray for when she rounded on the patient). He ordered that the patient be able to self-administer preservative free artificial tears in single-use vials prn (as needed). Because of excessive discharge, she also ordered that an assay for adenovirus be available on the patient's floor. The ophthalmologist planned to return the following day or ask the patient to come to follow up in the office in 24 hours should the patient be discharged.

\section{Scenario 1, Part IV}

Day 3: The troponin levels remained negative, and there was no change in the EKG. Mr. John had decreased chest pain and cough and other vital signs are normal. The patient stabilizes in 48 hours with the lab report positive for growth of streptococcus pneumoniae and confirming sensitivity to azithromycin. The blood cultures returned negative with no growth. He is discharged home with a diagnosis of pneumonia and conjunctivitis to follow up as an outpatient in seven days with his primary care physician. He is asked to see the ophthalmologist the next day to follow up on his viral conjunctivitis since he left the hospital before seeing him. At discharge, the nurse hands over to the patient the summary with the discharge instructions. 


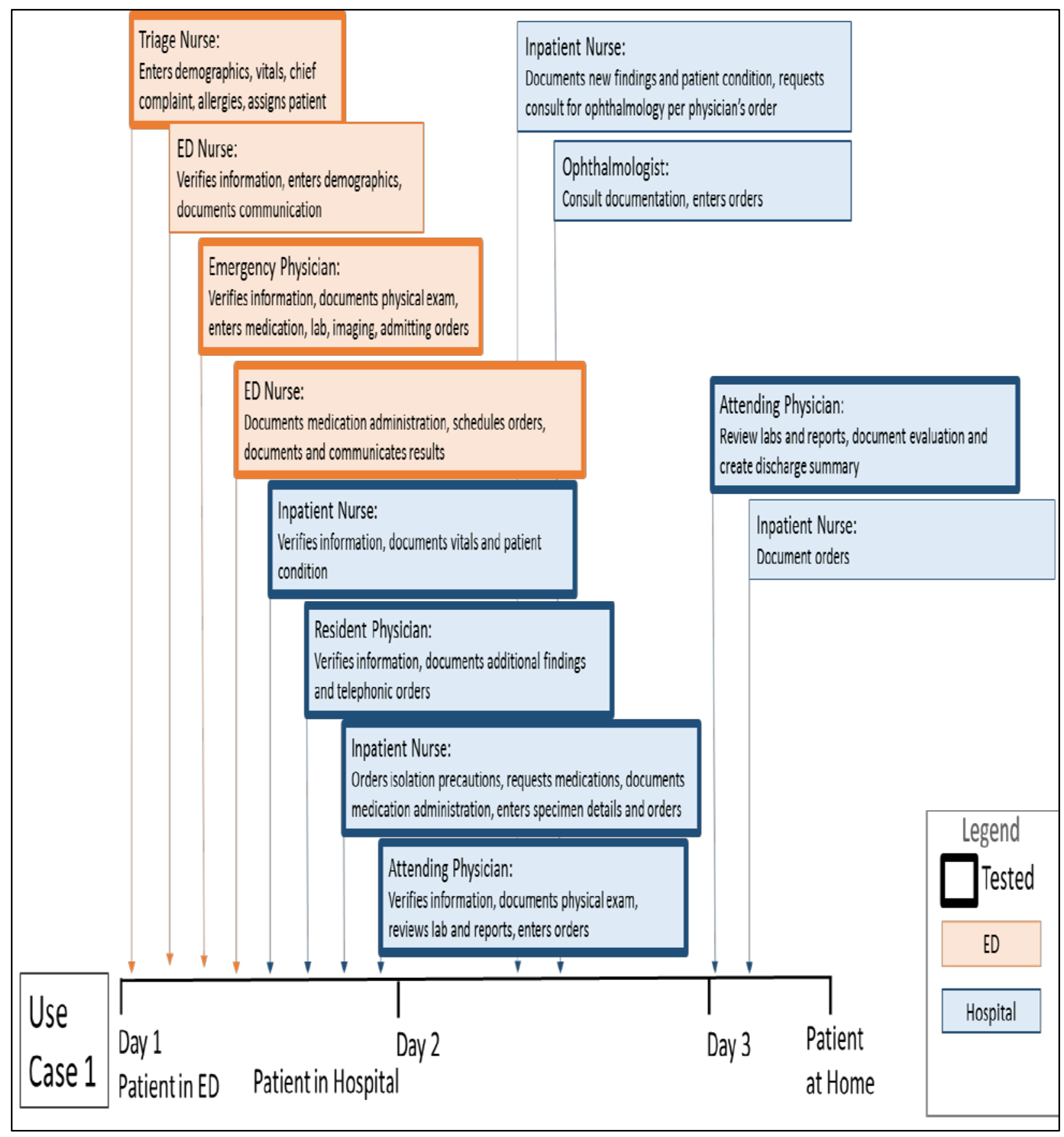

Figure 1. Sequence of events in first hospital stay included in validation testing 
Use Case 2: Outpatient care after second hospitalization

\section{Scenario 2, Part I}

Mr. John is now a 67-year-old male who presents to the Community General Hospital Emergency Department with complaints of headache, and a reported two short periods of confusion. He has just recovered from influenza that kept him bedridden at home for 8 days with vomiting and diarrhea. Mr. John is a known patient of Type 2 diabetes mellitus and hypercholesterolemia. The patient is triaged and taken into the Emergency Department. The ER nurse records the vital signs, which are within the normal limits. The Emergency physician orders electrolytes, CBC, a chest x-ray, CT scan, EKG, echo cardiogram, carotid artery Doppler and calls the internist who admits the patient to the ICU for evaluation of a possible stroke or TIA and orders an MRI. The MRI in the hospital is out of order and the MRI is not done. The echocardiogram results are scanned into the chart in the media section instead of cardiology where they are usually located. All other tests are negative except the lab tests come back with a low sodium and potassium and this is resolved within 24 hours by intravenous fluids. He receives orders for an MRI outpatient, Coumadin therapy for anticoagulation and teaching by the pharmacist.

Mr. John is sent home with a diagnosis of possible transient ischemic attack (TIA) and discharge instructions to follow up as an outpatient in seven days with his primary care physician and in three days with a neurologist. He receives five prescriptions to fill immediately.

\section{Scenario 2, Part II}

Upon coming into the office of his primary care physician on day two after discharge, Mr. John reports he feels much better but still gets headaches. The primary care doctor looks for the tests done at the hospital. He sees the MRI and echocardiogram were ordered but cannot find the results. The physician gets several calls during the outpatient encounter from the emergency department where another of his patients, Bill Bates, has arrived with chest pain so he stops and takes the urgent call. After addressing the needs of Mr. Bates, lab tests are drawn and Mr. John is sent home and will see the neurologist in the morning.

The urgent call is about Mr. Bill Bates. This interruption starts with the nurse in the primary care physician's office being called to the phone. The emergency department nurse says that Mr. Bates has come to the ED with a severe nosebleed and headache. The emergency department needs to know if Mr. Bates is on Coumadin. Mr. Bates cannot remember his medications and left them at home. 


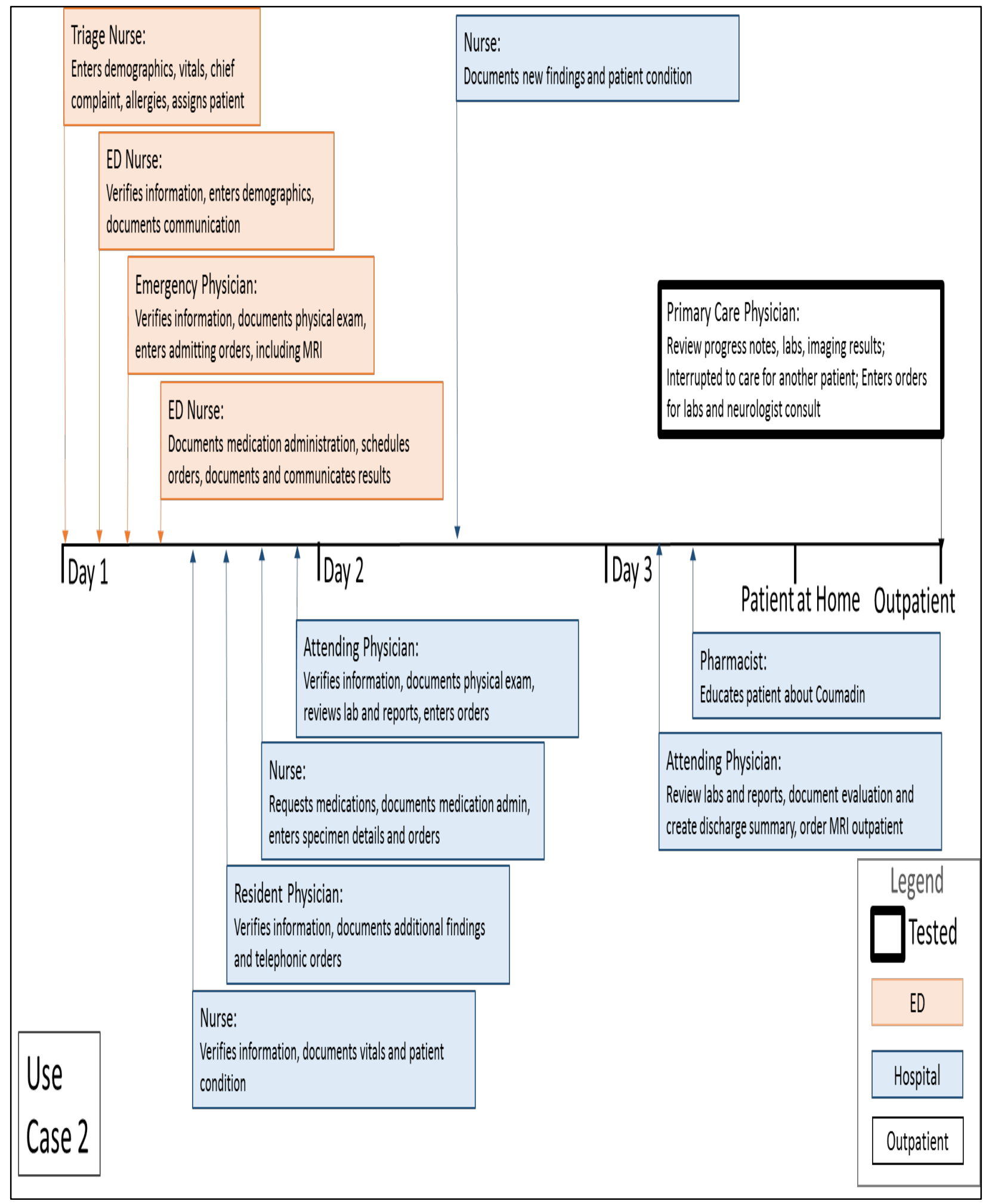

Figure 2. Sequence of events from second hospital day which are reviewed during the outpatient visit during validation testing 
The findings from the data analysis have implications for the design of use cases for ensuring safety-enhanced design in the context of these activities, in addition to others:

1. Ordering medications

2. Ordering laboratory tests

3. Ordering diagnostic imaging tests

4. Avoiding drug-drug, drug-allergy, and food-allergy interactions

5. Maintaining the problem list

6. Maintaining and reconciling the medication list

7. Maintaining the medication allergy list

8. Interpreting the recommendations from clinical decision support

9. Using the electronic medication administration record

10. Performing clinical information reconciliation and incorporation

11. Electronic prescribing of medications

When conducting summative usability testing evaluations, representative, appropriately licensed, participants simulate the roles of user categories (e.g., eligible professionals and nurses). The mapping of the listed activities above and the user category roles are:

1. Eligible professional (Medical Doctor, Nurse Practitioner, or Physician Assistant) role
a. Computerized provider order entry - medications
b. Computerized provider order entry - laboratory
c. Computerized provider order entry - diagnostic imaging
d. Clinical decision support
e. Drug-drug, drug-allergy interaction checks
f. Problem list
g. Medication allergy list
h. Medication list
i. Clinical information reconciliation and incorporation

2. Nurse role
a. Electronic medication administration record
b. Vital signs documentation
c. Clinical decision support
d. Drug-drug, drug-allergy interaction checks
e. Medication allergy list
f. Clinical information reconciliation and incorporation
g. Retrieve imaging results 
Table 3: Usability Test Tasks for Safety-Enhanced Design (Representative Use Cases)

\section{Use Case 1: First Hospital Stay}

Scenario 1, Part I: Triage Nurse

Participant is now logged in as the Triage Nurse

\begin{tabular}{|c|c|c|}
\hline Critical Task & Scenario Information & Usability Test Task \\
\hline $\begin{array}{l}\text { Patient chart has been } \\
\text { "initiated” } \\
\text { Nurse documents patient's } \\
\text { demographics }\end{array}$ & $\begin{array}{l}\text { Patient = Mr. William John } \\
\text { Age }=65 \text { years } \\
\text { Ethnicity = Hispanic } \\
\text { Sex = Male }\end{array}$ & $\begin{array}{l}\text { - Sign on to the System } \\
\text { - Open the patient record for Mr. William John } \\
\text { - Enter the provided demographic information } \\
\text { for this patient into the System }\end{array}$ \\
\hline \multirow[t]{3}{*}{$\begin{array}{l}\text { Nurse enters patient's } \\
\text { complaints, current } \\
\text { illnesses/conditions (history), } \\
\text { and allergies }\end{array}$} & $\begin{array}{l}\text { Patient complaints = severe } \\
\text { chest pain, difficulty } \\
\text { breathing, and productive } \\
\text { cough }\end{array}$ & \multirow[t]{3}{*}{$\begin{array}{l}\text { Enter the provided clinical information for this } \\
\text { patient into his patient record }\end{array}$} \\
\hline & $\begin{array}{l}\text { Current illnesses/conditions } \\
\text { (history) = Type } 2 \text { diabetes } \\
\text { mellitus, } \\
\text { Hypercholesterolemia }\end{array}$ & \\
\hline & $\begin{array}{l}\text { Allergies = thimerosal and } \\
\text { "pink sweetener" }\end{array}$ & \\
\hline $\begin{array}{l}\text { Nurse documents triage } \\
\text { information with disposition } \\
\text { to Emergency Department } \\
\text { (ED) }\end{array}$ & $\begin{array}{l}\text { Patient is triaged and taken to } \\
\text { the ED }\end{array}$ & $\begin{array}{l}\text { Enter information into the patient's record about } \\
\text { triaging and transporting him to the ED }\end{array}$ \\
\hline
\end{tabular}


Scenario 1, Part I: Emergency Department Nurse

Participant is now logged in as the ED Nurse

\begin{tabular}{|c|c|c|}
\hline Critical Task & Scenario Information & Usability Test Task \\
\hline $\begin{array}{l}\text { ED nurse verifies } \\
\text { information documented } \\
\text { by the Triage nurse }\end{array}$ & 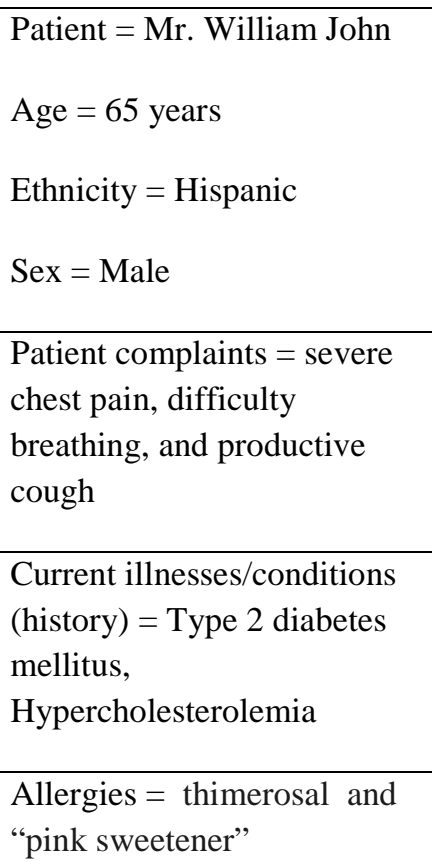 & $\begin{array}{l}\text { - Sign on to the System } \\
\text { - Open the record for Mr. William John } \\
\text { - Review the provided demographic and clinical } \\
\text { information that were entered into his record } \\
\text { by the Triage nurse }\end{array}$ \\
\hline $\begin{array}{l}\text { ED nurse records the } \\
\text { patient's vital signs, and } \\
\text { notifies the ED physician }\end{array}$ & $\begin{array}{l}\text { Temperature, Blood Pressure, } \\
\text { Respiratory Rate = within } \\
\text { normal limits for an adult } \\
\text { male }\end{array}$ & $\begin{array}{l}\text { - Enter the provided clinical information for this } \\
\text { patient into his record } \\
\text { - Enter a note stating that the ED physician was } \\
\text { notified about the increased heart rate and low } \\
\mathrm{O}_{2} \text { Saturation }\end{array}$ \\
\hline
\end{tabular}


Scenario 1, Part I: Emergency Physician

Participant is now logged in as the ED Physician

\begin{tabular}{|c|c|c|}
\hline Critical Task & Scenario Information & Usability Test Task \\
\hline $\begin{array}{l}\text { ED physician verifies } \\
\text { information documented } \\
\text { by the Triage and ED } \\
\text { nurses }\end{array}$ & 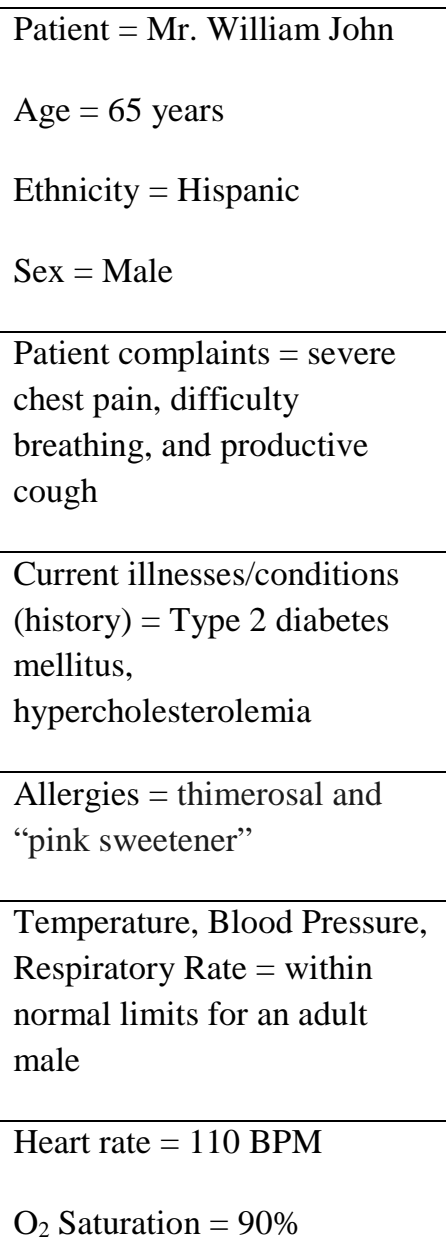 & $\begin{array}{l}\text { - Sign on to the System } \\
\text { - Open the record for Mr. William John } \\
\text { - Review the provided demographic and clinical } \\
\text { information that were entered into the record } \\
\text { for this patient by the Triage and ED nurses }\end{array}$ \\
\hline $\begin{array}{l}\text { ED physician orders } \mathrm{O}_{2} \\
\text { therapy, 12-lead EKG, lab } \\
\text { tests, a radiology test, } \\
\text { telemetry, medications, } \\
\text { and diabetic diet }\end{array}$ & $\begin{array}{l}\text { Orders }= \\
\text { - } \mathrm{O}_{2} \text { therapy per nasal } \\
\text { cannula STAT } \\
\text { - } 12 \text {-lead EKG } \\
\text { - Serial troponin levels } \\
\text { - Sputum for gram stain, now } \\
\text { - Complete Blood Count } \\
\text { (CBC) } \\
\text { - Finger-stick glucose } \\
\text { - Chest X-ray } \\
\text { - Continuous telemetry } \\
\text { - monitoring } \\
\text { - Long-acting insulin } \\
\text { - Regular insulin on sliding- } \\
\text { - } \text { scale } \\
\text { - Atorvastatin }\end{array}$ & $\begin{array}{l}\text { Enter the provided orders for this patient into his } \\
\text { record }\end{array}$ \\
\hline
\end{tabular}




\begin{tabular}{|l|l|l|}
\hline Critical Task & Scenario Information & Usability Test Task \\
\hline & $\bullet$ Vitamins & \\
& $\bullet$ Aspirin & \\
& $\bullet$ Azithromycin & \\
& & \\
\hline
\end{tabular}

Scenario 1, Part I: Emergency Department Nurse

Participant is now logged in as the ED Nurse

\begin{tabular}{|c|c|c|}
\hline Critical Task & Scenario Information & Usability Test Task \\
\hline $\begin{array}{l}\text { ED nurse documents } \\
\text { medication administration, } \\
\mathrm{O}_{2} \text { therapy, EKG } \\
\text { performed, lab specimens } \\
\text { obtained, glucose test } \\
\text { performed, and telemetry } \\
\text { monitoring }\end{array}$ & $\begin{array}{l}\text { Treatments \& tests } \\
\text { performed = } \\
\text { - Continuous } \mathrm{O}_{2} \text { therapy } \\
\text { per nasal cannula initiated } \\
\text { - Continuous telemetry } \\
\text { monitoring initiated } \\
\text { - 12-lead EKG completed } \\
\text { - Finger-stick glucose } \\
\text { completed } \\
\text { Lab specimens collected = } \\
\text { - Serial troponin level } \\
\text { - Sputum for gram stain } \\
\text { - Complete Blood Count } \\
\text { (CBC) } \\
\text { Medications administered = } \\
\text { - Regular insulin on } \\
\text { - Atiding-scale } \\
\text { - Vitorvastatin } \\
\text { - Aspirin } \\
\text { - Azithromycin }\end{array}$ & $\begin{array}{l}\text { - Sign on to the System } \\
\text { - Open the record for Mr. William John } \\
\text { - Enter the provided information for medication } \\
\text { administration, } \mathrm{O}_{2} \text { therapy initiated, EKG } \\
\text { completed, finger-stick glucose completed (and } \\
\text { result), and specimens collected for this patient } \\
\text { into his record }\end{array}$ \\
\hline
\end{tabular}


Scenario 1, Part I: Emergency Physician

Participant is now logged in as the ED Physician

\begin{tabular}{|l|l|l|}
\hline \multicolumn{1}{|c|}{ Critical Task } & \multicolumn{1}{|c|}{ Scenario Information } & \multicolumn{1}{c|}{ Usability Test Task } \\
\hline $\begin{array}{l}\text { ED physician reviews } \\
\text { results of diagnostic tests }\end{array}$ & $\begin{array}{l}\text { Diagnostic Test Results }= \\
\text { - Chest X-ray confirms } \\
\text { pneumonia } \\
\text { - Troponin is negative } \\
\text { - EKG shows abnormal, } \\
\text { but non-significant, ST } \\
\text { segment changes }\end{array}$ & $\begin{array}{l}\text { - Sign on to the System } \\
\text { - Open the record for Mr. William John } \\
\text { Find and review the provided diagnostic test }\end{array}$ \\
\hline $\begin{array}{l}\text { ED physician orders the } \\
\text { patient to be admitted as an and } \\
\text { inpatient }\end{array}$ & $\begin{array}{l}\text { Admit patient to Medical- } \\
\text { Surgical unit today for } \\
\text { observation and treatment }\end{array}$ & Enter admission order into the patient's record \\
\hline
\end{tabular}

\section{Scenario 1, Part II: Inpatient Nurse}

Participant is now logged in as the Inpatient Nurse

\begin{tabular}{|c|c|c|}
\hline Critical Task & Scenario Information & Usability Test Task \\
\hline $\begin{array}{l}\text { Inpatient nurse receives } \\
\text { the patient on the } \\
\text { Medical-Surgical unit and } \\
\text { verifies information } \\
\text { documented by the Triage } \\
\text { nurse, ED nurse, and ED } \\
\text { physician, and reviews } \\
\text { diagnostic test results and } \\
\text { the order for inpatient } \\
\text { admit }\end{array}$ & 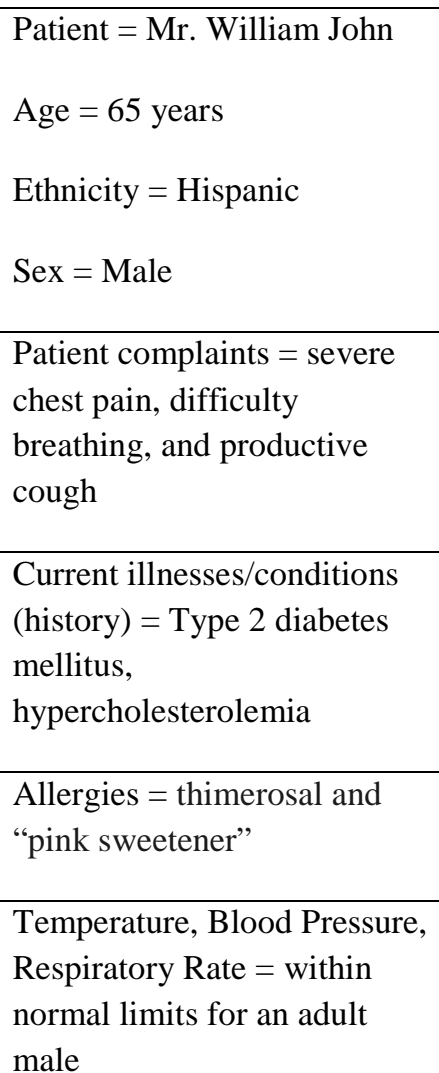 & $\begin{array}{l}\text { - } \quad \text { Sign on to the System } \\
\text { - } \quad \text { Open the record for Mr. William John } \\
\text { information } \\
\text { - } \quad \text { Find and verify the documented patient } \\
\text { complaints, current illnesses/conditions, } \\
\text { allergy, vital sign, and } \mathrm{O}_{2} \text { saturation } \\
\text { information } \\
\text { - Find and review the documented medication } \\
\text { - } \quad \text { Find and review the information documented } \\
\text { - } \quad \text { Find and review the diagnostic test results } \\
\text { - } \quad \text { Find and verify the inpatient admit orders }\end{array}$ \\
\hline
\end{tabular}




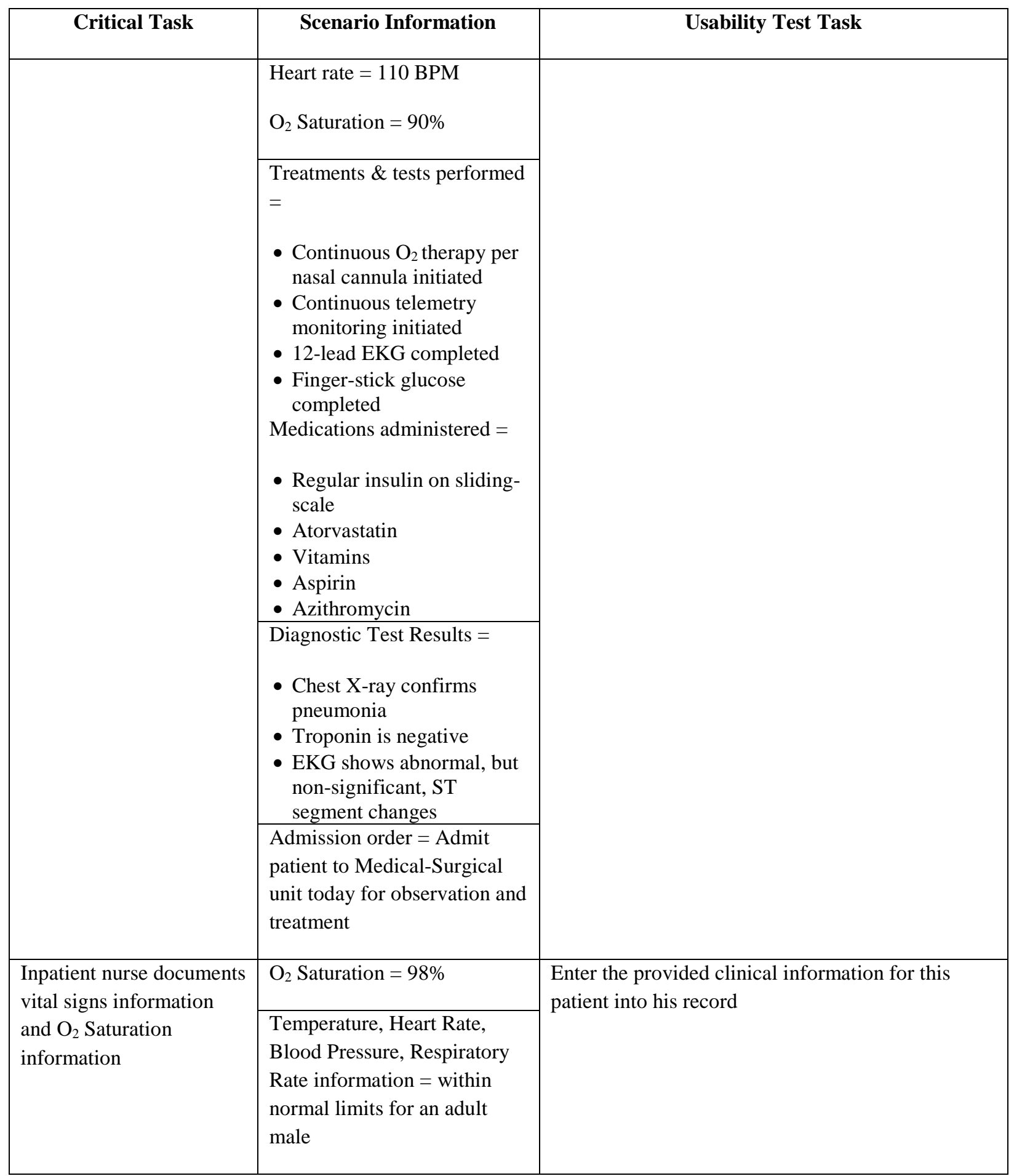




\section{Scenario 1, Part II: Attending Physician}

Participant is now logged in as the Attending Physician

\begin{tabular}{|l|l|l|}
\hline \multicolumn{1}{|c|}{ Critical Task } & \multicolumn{1}{|c|}{ Scenario Information } & \multicolumn{1}{c|}{ Usability Test Task } \\
\hline $\begin{array}{l}\text { Attending physician makes } \\
\text { rounds and orders the } \mathrm{O}_{2} \\
\text { Therapy changed to as } \\
\text { needed }\end{array}$ & $\begin{array}{l}\text { Order = change } \mathrm{O}_{2} \text { therapy } \\
\text { per nasal cannula from } \\
\text { "continuous” to “prn, to } \\
\text { maintain } \mathrm{O}_{2} \text { Saturation }> \\
96 \% \text { " }\end{array}$ & $\begin{array}{l}\text { - Sign on to the System } \\
\text { - Open the record for Mr. William John } \\
\text { Enter the provided } \mathrm{O}_{2} \text { therapy change order into } \\
\text { this patient’s record }\end{array}$ \\
\hline
\end{tabular}

Scenario 1, Part III: Inpatient Nurse

Participant is now logged in as the Inpatient Nurse

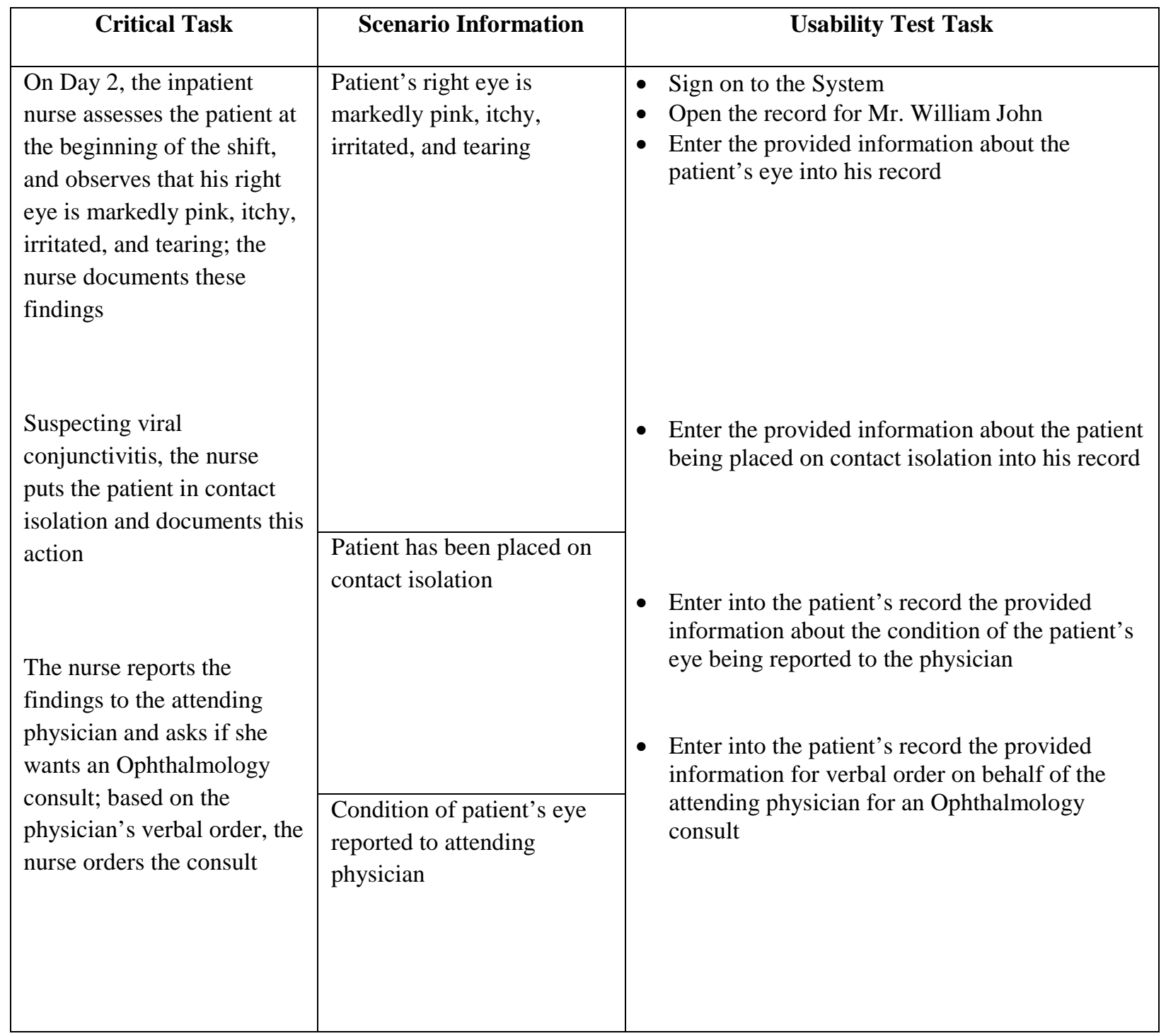




\begin{tabular}{|l|l|l|}
\hline Critical Task & \multicolumn{1}{|c|}{ Scenario Information } & Usability Test Task \\
\hline & $\begin{array}{l}\text { Ophthalmology consult for } \\
\text { possible viral conjunctivitis } \\
\text { ASAP }\end{array}$ & \\
\hline
\end{tabular}

\section{Scenario 1, Part III: Ophthalmologist}

Participant is now logged in as the Ophthalmologist

\begin{tabular}{|c|c|c|}
\hline Critical Task & Scenario Information & Usability Test Task \\
\hline $\begin{array}{l}\text { The ophthalmologist } \\
\text { performs a consult and } \\
\text { documents her findings and } \\
\text { plan }\end{array}$ & $\begin{array}{l}\text { - Patient has a history of } \\
\text { being in contact with a } \\
\text { family member who } \\
\text { recently had "pink eye” } \\
\text { - Patient was an occasional } \\
\text { contact lens wearer, but } \\
\text { has not been wearing } \\
\text { them recently } \\
\text { - Visual acuity, intraocular } \\
\text { pressure, and ophthalmic } \\
\text { exam are normal except } \\
\text { for signs and symptoms } \\
\text { consistent with viral } \\
\text { conjunctivitis } \\
\text { - Plan: will return } \\
\text { tomorrow or ask patient to } \\
\text { schedule a follow-up visit } \\
\text { in } 24 \text { hours if patient is } \\
\text { discharged before rounds } \\
\text { tomorrow }\end{array}$ & $\begin{array}{l}\text { - Sign on to the System } \\
\text { - Open the record for Mr. William John } \\
\text { - Enter the provided findings and Plan into this } \\
\text { patient's record }\end{array}$ \\
\hline $\begin{array}{l}\text { The ophthalmologist orders } \\
\text { an eye medication }\end{array}$ & $\begin{array}{l}\text { Topical tetracaine 1\%, to } \\
\text { be administered in both } \\
\text { eyes by ophthalmologist } \\
\text { (have bottles available in } \\
\text { patient's medication tray } \\
\text { for physician's rounds }\end{array}$ & $\begin{array}{l}\text { Enter the provided order for the eye medication } \\
\text { into the patient's record }\end{array}$ \\
\hline $\begin{array}{l}\text { The ophthalmologist orders } \\
\text { eye drops for the patient to } \\
\text { administer to himself }\end{array}$ & $\begin{array}{l}\text { Preservative-free artificial } \\
\text { tears in single-use vials } \\
\text { for patient self- } \\
\text { administration }\end{array}$ & $\begin{array}{l}\text { Enter the provided order for the artificial tears } \\
\text { into the patient's record }\end{array}$ \\
\hline $\begin{array}{l}\text { The ophthalmologist orders } \\
\text { an assay for adenovirus }\end{array}$ & $\begin{array}{l}\text { - Keep an assay for } \\
\text { adenovirus available on } \\
\text { the patient's hospital unit }\end{array}$ & $\begin{array}{l}\text { Enter the provided order for the adenovirus assay } \\
\text { into the patient's record }\end{array}$ \\
\hline
\end{tabular}


Scenario 1, Part IV: Attending Physician

Participant is now logged in as the Attending Physician

\begin{tabular}{|c|c|c|}
\hline Critical Task & Scenario Information & Usability Test Task \\
\hline $\begin{array}{l}\text { Attending physician reviews } \\
\text { diagnostic test results, vital } \\
\text { signs, clinical observations }\end{array}$ & $\begin{array}{ll}\text { - } & \text { Troponin levels } \\
& \text { remained negative } \\
\text { - } & \text { No change in the EKG } \\
\text { - } & \text { Decreased chest pain and } \\
& \text { cough } \\
\text { - } & \text { Vital signs are normal } \\
\text { - } & \text { Patient is stable } \\
\text { - } & \text { Sputum culture and } \\
\text { susceptibility report is } \\
\text { positive for growth of } \\
\text { streptococcus } \\
\text { pneumoniae with } \\
\text { sensitivity to } \\
\text { azithromycin } \\
\text { - } \text { Blood cultures were } \\
\text { negative/no growth }\end{array}$ & $\begin{array}{l}\text { - } \\
\text { - } \\
\text { - } \\
\text { Open on the record for Mr. William John } \\
\text { information that is documidented in the patient } \\
\text { record, including diagnostic test results, vital } \\
\text { signs, and other assessments }\end{array}$ \\
\hline $\begin{array}{l}\text { Attending physician } \\
\text { documents a discharge } \\
\text { summary }\end{array}$ & $\begin{array}{l}\text { The troponin levels have } \\
\text { remained negative, and there } \\
\text { has been no change in the } \\
\text { EKG. Mr. John has } \\
\text { decreased chest pain and } \\
\text { cough, and other vital signs } \\
\text { are normal. The patient has } \\
\text { stabilized over the past } 48 \\
\text { hours. The lab report for } \\
\text { sputum specimen is positive } \\
\text { for growth of streptococcus } \\
\text { pneumonia, with } \\
\text { confirmation of sensitivity to } \\
\text { azithromycin. The blood } \\
\text { cultures returned negative } \\
\text { with no growth. Patient to be } \\
\text { discharged home with a } \\
\text { diagnosis of pneumonia and } \\
\text { conjunctivitis. }\end{array}$ & $\begin{array}{l}\text { Enter the provided discharge summary } \\
\text { information into the patient's record }\end{array}$ \\
\hline $\begin{array}{l}\text { Attending physician orders } \\
\text { the patient to be discharged } \\
\text { from the hospital to home } \\
\text { with a final diagnosis of } \\
\text { pneumonia and } \\
\text { conjunctivitis, and with } \\
\text { instructions to schedule a } \\
\text { visit with his primary care } \\
\text { physician and a }\end{array}$ & $\begin{array}{l}\text { Discharge patient to home } \\
\text { Final diagnosis pneumonia } \\
\text { and conjunctivitis } \\
\text { Patient to schedule a visit } \\
\text { with his primary care } \\
\text { physician in seven days }\end{array}$ & $\begin{array}{l}\text { Enter the provided discharge order information } \\
\text { into the patient's record }\end{array}$ \\
\hline
\end{tabular}




\begin{tabular}{|l|l|l|}
\hline \multicolumn{1}{|c|}{ Critical Task } & \multicolumn{1}{|c|}{ Scenario Information } & Usability Test Task \\
\hline recommendation to schedule & $\begin{array}{l}\text { Recommended that patient } \\
\text { a visit with the }\end{array}$ & \\
ophthalmologist the next & ophthalmologist for & \\
day for follow up on his & tomorrow for follow up on & \\
viral conjunctivitis & the viral conjunctivitis & \\
\hline
\end{tabular}


Use Case 2: Outpatient Care Testing (inpatient data is only to prepopulate hospital chart not to test)

\section{Scenario 2, Part I: Triage Nurse}

Participant is now logged in as the Triage Nurse,

\begin{tabular}{|c|c|c|}
\hline Critical Task & Scenario Information & Usability Test Task \\
\hline $\begin{array}{l}\text { Patient chart has been } \\
\text { "initiated” } \\
\text { Nurse documents patient's } \\
\text { demographics }\end{array}$ & $\begin{array}{l}\text { Patient = Mr. William John } \\
\text { Age }=67 \text { years } \\
\text { Ethnicity = Hispanic } \\
\text { Sex = Male }\end{array}$ & $\begin{array}{l}\text { - Sign on to the System } \\
\text { - Open the patient record for Mr. William John } \\
\text { - Enter/verify the provided demographic } \\
\text { information for this patient into the System }\end{array}$ \\
\hline \multirow{2}{*}{$\begin{array}{l}\text { Nurse enters patient's } \\
\text { complaints, current } \\
\text { illnesses/conditions (history), } \\
\text { and allergies }\end{array}$} & $\begin{array}{l}\text { Patient complaints }= \\
\text { headache and reported two } \\
\text { short periods of confusion }\end{array}$ & \multirow[t]{2}{*}{$\begin{array}{l}\text { Enter the provided clinical information for this } \\
\text { patient into his patient record }\end{array}$} \\
\hline & $\begin{array}{l}\text { Current illnesses/conditions } \\
\text { (history) = Type } 2 \text { diabetes } \\
\text { mellitus, } \\
\text { hypercholesterolemia }\end{array}$ & \\
\hline $\begin{array}{l}\text { Nurse documents triage } \\
\text { information with disposition } \\
\text { to Emergency Department } \\
\text { (ED) }\end{array}$ & $\begin{array}{l}\text { Patient is triaged and taken to } \\
\text { the ED }\end{array}$ & $\begin{array}{l}\text { Enter information into the patient's record about } \\
\text { triaging and transporting him to the ED }\end{array}$ \\
\hline
\end{tabular}

\section{Scenario 2, Part I: Emergency Department Nurse}

Participant is now logged in as the ED Nurse

\begin{tabular}{|l|l|ll|}
\hline \multicolumn{1}{|c|}{ Critical Task } & \multicolumn{1}{|c|}{ Scenario Information } & Usability Test Task \\
\hline $\begin{array}{l}\text { ED nurse records the } \\
\text { patient's vital signs }\end{array}$ & $\begin{array}{l}\text { Temperature, Heart Rate, } \\
\text { Blood Pressure, Respiratory } \\
\text { Rate = within normal limits } \\
\text { for an adult male }\end{array}$ & $\bullet \begin{array}{l}\text { Sign on to the System } \\
\text { Open the record for Mr. William John } \\
\text { Enter the provided clinical information for this } \\
\text { patient into his record }\end{array}$ \\
\hline
\end{tabular}


Scenario 2, Part I: Emergency Physician

Participant is now logged in as the ED Physician

\begin{tabular}{|c|c|c|}
\hline Critical Task & Scenario Information & Usability Test Task \\
\hline $\begin{array}{l}\text { ED physician orders lab } \\
\text { tests, a radiology test, } \\
\text { EKG, and other diagnostics } \\
\text { tests }\end{array}$ & $\begin{array}{l}\text { Orders }= \\
\text { - Electrolytes } \\
\text { - Complete Blood Count } \\
\text { (CBC) } \\
\text { - Chest X-ray } \\
\text { - CT Scan of head } \\
\text { - EKG } \\
\text { - ECHO cardiogram } \\
\text { - Carotid artery Doppler }\end{array}$ & $\begin{array}{l}\text { - Sign on to the System } \\
\text { - Open the record for Mr. William John } \\
\text { - Enter the provided orders for this patient into } \\
\text { his record }\end{array}$ \\
\hline
\end{tabular}

Scenario 2, Part I: Internist

Participant is now logged in as the Internist

\begin{tabular}{|c|c|c|}
\hline Critical Task & Scenario Information & Usability Test Task \\
\hline $\begin{array}{l}\text { Internist orders admit to } \\
\text { ICU and additional } \\
\text { diagnostics testing }\end{array}$ & $\begin{array}{l}\text { Orders }= \\
\text { - Admit to ICU for } \\
\text { evaluation of possible } \\
\text { stroke or TIA } \\
\text { - MRI }\end{array}$ & $\begin{array}{l}\text { - Sign on to the System } \\
\text { - Open the record for Mr. William John } \\
\text { - Enter the provided orders for this patient into } \\
\text { his record }\end{array}$ \\
\hline $\begin{array}{l}\text { Internist reviews results of } \\
\text { diagnostic testing }\end{array}$ & $\begin{array}{l}\text { - Electrolytes results = low } \\
\mathrm{Na}^{+} \text {and } \mathrm{K}^{+} \\
\text {- Complete Blood Count } \\
\text { (CBC) result = normal } \\
\text { - Chest X-ray = negative } \\
\text { - CT Scan of head = } \\
\text { negative } \\
\text { - EKG = negative } \\
\text { - ECHO cardiogram = } \\
\text { misfiled in media section } \\
\text { of patient record } \\
\text { - Carotid artery Doppler = } \\
\text { negative }\end{array}$ & Review the provided results in the patient record \\
\hline $\begin{array}{l}\text { Internist orders outpatient } \\
\text { diagnostic testing, } \\
\text { medication with teaching, } \\
\text { and discharge with follow- } \\
\text { up }\end{array}$ & $\begin{array}{l}\text { Orders = } \\
\text { - MRI outpatient } \\
\text { - Coumadin with teaching } \\
\text { by pharmacist } \\
\text { - Discharge to home, final } \\
\text { diagnosis possible TIA } \\
\text { - Patient to schedule a visit } \\
\text { with his primary care } \\
\text { physician in seven days }\end{array}$ & $\begin{array}{l}\text { Enter the provided discharge orders for this patient } \\
\text { into his record }\end{array}$ \\
\hline
\end{tabular}




\begin{tabular}{|l|l|l|}
\hline Critical Task & \multicolumn{1}{|c|}{ Scenario Information } & Usability Test Task \\
\hline & $\begin{array}{l}\text { - Patient to schedule a visit } \\
\text { with neurologist in three } \\
\text { days }\end{array}$ & \\
\hline
\end{tabular}

\section{Scenario 2, Part II: Primary Care Physician}

Participant is now logged in as the Primary Care Physician

\begin{tabular}{|c|c|c|}
\hline Critical Task & Scenario Information & Usability Test Task \\
\hline $\begin{array}{l}\text { Primary care physician } \\
\text { looks for diagnostic results } \\
\text { from tests performed in the } \\
\text { hospital }\end{array}$ & $\begin{array}{l}\text { - } \text { MRI and ECHO } \\
\text { cardiogram results not } \\
\text { available } \\
\text { - Electrolytes results = low } \\
\mathrm{Na}^{+} \text {and } \mathrm{K}^{+} \\
\text {- Complete Blood Count } \\
\text { (CBC) result = normal } \\
\text { - Chest X-ray = negative } \\
\text { - CT Scan of head = } \\
\text { negative } \\
\text { - EKG = negative } \\
\text { - ECHO cardiogram = } \\
\text { misfiled in media section } \\
\text { of patient record } \\
\text { - Carotid artery Doppler = } \\
\text { negative }\end{array}$ & $\begin{array}{l}\text { - Sign on to the System } \\
\text { - } \text { Open the record for Mr. William John } \\
\text { in the patient's record } \\
\text { - Review the provided results that are available in } \\
\text { the patient's record }\end{array}$ \\
\hline $\begin{array}{l}\text { Primary care physician is } \\
\text { interrupted by call from } \\
\text { Emergency department } \\
\text { regarding Mr. Bates who } \\
\text { has presented with a nose } \\
\text { bleed. }\end{array}$ & $\begin{array}{l}\text { Physician moves to Mr. } \\
\text { Bates chart. Physician opens } \\
\text { Mr. Bates chart and reviews } \\
\text { his history and medication. }\end{array}$ & 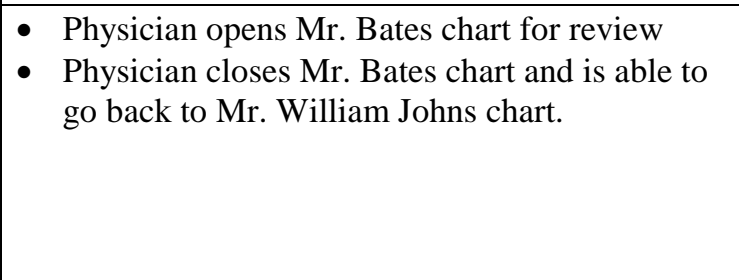 \\
\hline
\end{tabular}




\section{Empirically Based Human Factors Guidance for Safety- Enhanced Design of Health Information Technology}

Human factors guidance for safe and usable design exists for a number of safety-critical domains, but not currently for health information technology (HIT) design. For example, the Human Factors Design Standard (HFDS) is a compilation of human factors principles and guidance for the procurement, design, development, and testing of aviation systems, facilities, and equipment. ${ }^{22}$ Within this document, the principle of 'simplicity' is defined as "Information should be presented simply and in a well-organized manner." In order to achieve this principle, the following guidance is provided, along with other recommendations: "Information should be presented in consistent, predictable locations." Based upon our empirical findings, detailed in the previous section, as well as a comprehensive review of existing standards under NIST Contract Number SB134110CN0107, we provide a limited set of high-priority guidance below. These guidelines for standardization are targeted uniquely at eliminating 'never events' and associated patient harm by proactively addressing and mitigating the root causes of critical use errors from EHR design and implementation elements, as distinguished in our framework on the relationship between usability and patient safety, as described in Figure 3 of NISTIR 7804 Technical Evaluation, Testing and Validation of the Usability of Electronic Health Records. ${ }^{23}$

The empirically based human factors guidance for safety-enhanced design is:

1. Consistently display information critical to patient identification in a reserved area (specified below) to avoid wrong patient errors

1.1 Patient identification information shall be displayed in the upper left hand corner of all screens/windows in a consistent order; so that users can efficiently and accurately find and verify patient identity

1.2 The information shall continue to be displayed in the same location regardless of scrolling or other navigational mechanisms to move within the screen/window

1.3 The order shall be to first display the patient's name with the last (family) name capitalized, followed by a comma and then first (given) name, middle name, and modifier, followed by date of birth using e.g., Nov 9, 1961 format and age and gender, and then followed by MRN number.

1.4 For mobile devices or tablets with smaller screen sizes, it may be preferable to display the information horizontally using the same ordering convention and white space between the three elements. The information should be demarcated on the bottom 
and/or the side, such as by employing white space, shading, or a line, from additional optional identifiers

1.5 An example of this reserved area is:

\section{SMITH, Walter Joseph III \\ Nov 9, 1961 (53 yo M) \\ MRN1348887}

a. NAME: The last (family) name should be first and capitalized followed by a ', and space prior to a capitalized first (given) name with the rest of the name in lower case. The capitalization is used to distinguish the last name in cases of ambiguity (e.g., Clark Kelly could be Clark KELLY or Kelly CLARK). It also reduces variation for names with multiple capitalizations, such as McDonald.

b. NAME MODIFIER: In the absence of a modifier (e.g., Jr, Sr, III), nothing shall be displayed in that location

c. DATE: The month represented as the first three letters of the month (or four in languages other than English such as Italian where this is needed to disambiguate months) shall be represented with a capitalized first letter with the rest in lower case in order to make the capitalized last name more distinguishable quickly on the display. The full year shall be displayed as four numeric digits

d. AGE: Displaying the age reduces the cognitive work required by the user to convert date of birth into age. For years old, the display convention is 'yo' with a space after the number, rounded down to the nearest digit. Similarly, months old is displayed as 'mo', weeks old as 'wo', and days old as 'do'. In Neonatal Intensive Care Units, DOL 1 is often used for the first day of life, which corresponds to 0 days old. Similarly, DOL 2 is the second day of life. Decisions on when to display yo, mo, wo, do, and DOL are expected to vary by institution. For example, a hospital may display DOL for the first five days of life, followed by do until 30 days old, then wo until 24 weeks old, then mo until 24 months old, and finally yo after 24 months of age. For the purposes of tracking accuracy of information, it should be possible to display 'on demand' the value of the age in the original format in which it was stored or transferred with interoperable systems. Age for patients should not be displayed in values of less than 1 unit (e.g., 0.0001 yo)

e. GENDER: For gender, the display options should be M or Male for Male, F or Female for Female, and Other. Additional details specifying subcategories under Other, as necessary, shall be viewable on demand, such as transgender, or reasons for a gender change

f. MRN: The allocation of digits to the Medical Record Number (MRN) should be able to be modified in the future to accommodate future changes. Additional identifiers such as care episode can be included on this line after the MRN. The 
font size for MRN and other numeric identifiers can be smaller than the other information displayed in the reserved area or placed to the right of the name and date of birth information, but should still be viewable by older users. ${ }^{4} \mathrm{MRN}$ information may be displayed in the reserved area only in response to an explicit user action and/or when a barcoded wristband is scanned. Other identifiers, such as encounter numbers, shall not be displayed in the reserved area in order to reduce the likelihood of confusing the identifiers

g. ADDITIONAL IDENTIFIERS: Optional additional identifiers shall not be included in the reserved area, as defined by being below a clearly demarcated horizontal line or to the right of the area above the demarcation line. The display of optional identifiers should not cover task-critical information except for short periods 'on demand.' Additional optional identifiers include:

1) Place of birth

2) Picture. Note: Recommended to be a color picture of an individual patient taken within the last 5 years, with no other individuals in the picture, and as a close-up of the head facing the camera.

3) Biometrics

4) Genome

5) Barcode

6) Episode/encounter code

7) Suspected, confirmed or ruled out to have a highly infectious disease (e.g., 'Confirmed Ebola'), etc.

\footnotetext{
${ }^{4}$ Kochurova, Olga, Joan K. Portello, and Mark Rosenfield. "Is the $3 \times$ reading rule appropriate for computer users?." Displays 38 (2015): 38-43.
} 


\section{Provide visual cues to reduce risks of entering information and writing orders in the wrong patient's chart}

2.1 Visually differentiate a chart ${ }^{5}$ that enables a user to have unrestricted access to input information (i.e., input mode) from a chart, which restricts the user's ability to input information (i.e., view-only mode)

2.2 Enable user to enter information on only one patient's chart at one time

2.3 Enable user to have a chart in view-only mode in parallel with a chart with unrestricted access to input information in order to support specialty-specific care needs (e.g., coordinated mother and child care following a birth, coordinated care of multiple birth patients)

2.4 Enable user to easily transition from the current chart with unrestricted access to input information to another chart by a deliberate action (i.e., identification/activation of the patient chart), by the user.

2.4.1 Categories of charts that are likely to be needed by clinical providers are 1 ) charts for patients that are scheduled to be seen in the near future (e.g., 24 hours), 2) charts for patients that have recently had information input into them, 3) charts that have ordered laboratory tests or imaging tests that are pending results, and 4) charts that have planned actions such as documenting progress notes which have not yet been completed.

2.4.2 Easily transition implies that context has to be preserved in a way that is clear to the user when the user transitions to another chart and back to a previous chart; and that it is easy to find and identify a desired patient's chart for any relevant patient in the system. Context should be preserved in these transitions such that unsaved work in progress text should be preserved by the system until saved (or deleted) by the user

2.5 Visually distinguish the mechanism for moving within a single patient's chart and transitioning from one chart with unrestricted access to input information to another

${ }^{5}$ In the 2002 article "Maintaining a Legally Sound Health Record." Journal of AHIMA 73(2), a chart is defined as "generated at or for a healthcare organization as its business record and is the record that would be released upon request. It does not affect the discoverability of other information held by the organization. The custodian of the legal health record is the health information manager in collaboration with information technology personnel. HIM professionals oversee the operational functions related to collecting, protecting, and archiving the legal health record, while information technology staff manage the technical infrastructure of the electronic health record." 


\section{Support efficient and easy identification of inaccurate, outdated, or inappropriate items in lists of grouped information by having information presented simply and in a well-organized manner.}

Ways to achieve this include the following:

3.1 Lists of patients assigned to a particular clinician user should be presented in consistent, predictable locations within and across displays and print-outs and the content should not vary based on display location.

3.2 The status of a note and order as draft as compared to final shall be clearly indicated on appropriate displays.

3.3 Clearly indicate the method by which the system saves information, whether auto-save or requiring deliberate action to save, or combinations thereof.

3.4 Inputted information should be automatically saved when a user transitions from one chart to another.

3.5 The language used should be task-oriented and familiar to users, including being consistent with expectations based upon clinical training.

3.6 Enable a user to easily order medications that have a high likelihood of being the appropriate medication, dose, and route. The likelihood is increased when displays are tailored to specialty-specific user requirements, comply with national evidence-based recommendations, are in accordance with system, organizational, unit, or individual provider preferences specified in advance, or are similar to orders made by the same physician on similar patients, on the same patient in the past, or providers with similar characteristics.

3.7 Support assessing relationships of displayed information and allowing users with appropriate permissions to modify locations and relationships for inaccurately placed information, including laboratory results, imaging results, pathology results, consult notes, and progress notes. This includes information within a single patient's chart as well as information placed in the wrong patient's chart. The information about the time and person that made the change should be viewable on demand. 


\section{$7 \quad$ Conclusions}

This report examines the use of EHRs and their potential to improve and hinder healthcare quality and patient safety. We drew upon five different methods of data collection, utilized cross-cutting analytic methods, and had analysts from different disciplines and perspectives. The results demonstrate strong congruence among the data, across the methods, and amongst the analysts. Three major critical use risk areas surfaced during analysis: 1) Identification of information; 2) Consistency of information; and 3) Integrity of information. These three areas are consistent with findings from other studies that examined the use of EHRs.

Ultimately, the data from this study demonstrate that during safety-critical tasks and times, patient safety is negatively affected, in part because mistakes and critical use errors occur more frequently and because users are highly frustrated, and thus more likely to employ workarounds, such as relying upon supplemental artifacts, e.g., paper 'shadow charts' or whiteboards. Figure 3 below highlights the ways in which problems with identification, consistency, and integrity of information can result in suboptimal and unsafe patient care.

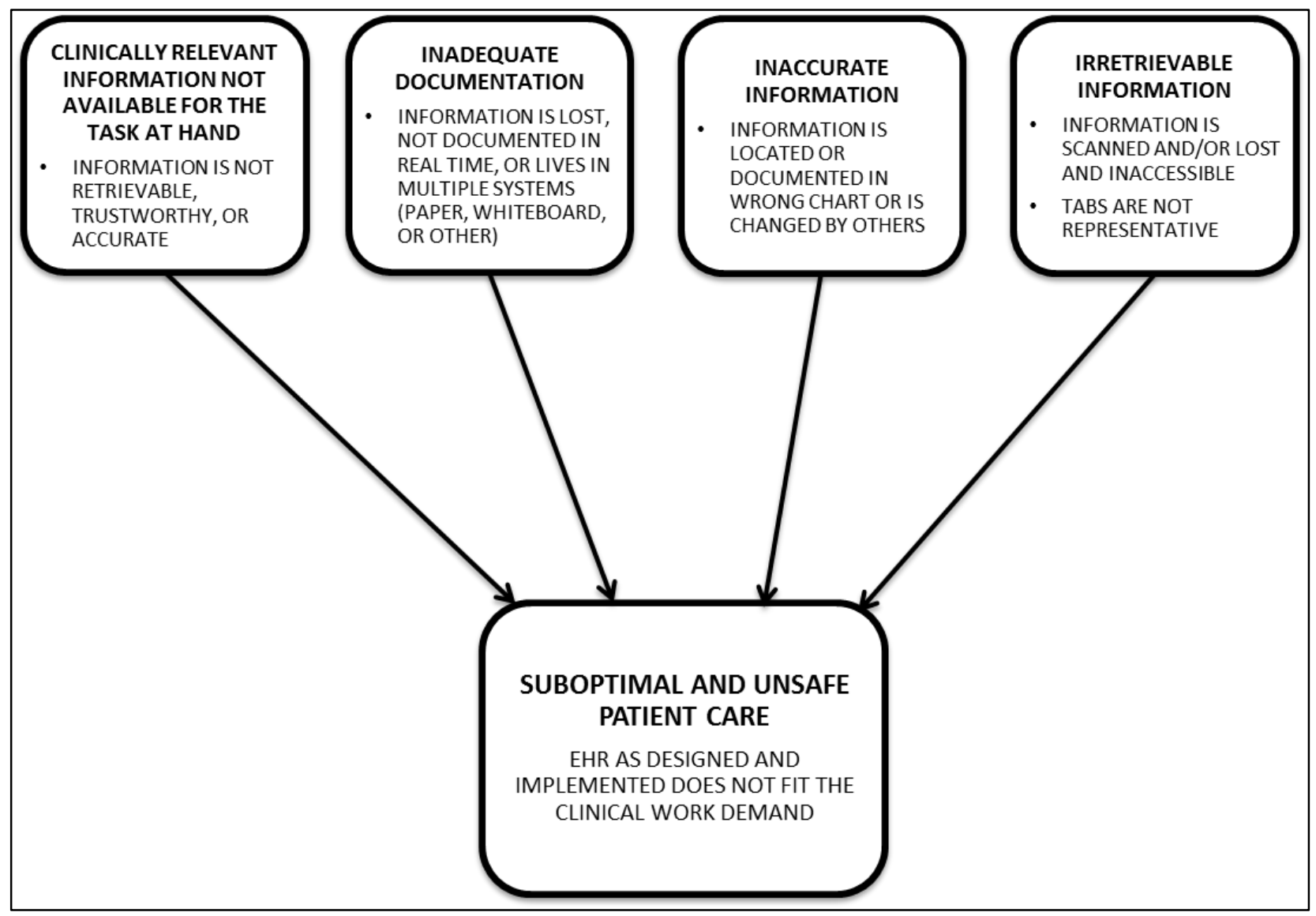

Figure 3. Relationship between usability findings and safe and effective clinical care 
In accordance with the empirical evidence, and in order to make care more optimal and safe, we provided human factors guidance for improving the usability of EHRs. There are three areas for this guidance:

1) Consistently displaying information critical to patient identification in a reserved area to avoid wrong patient errors,

2) Providing cues to reduce risks of entering information and writing orders in the wrong patient's chart, and

3) Supporting efficient and easy identification of inaccurate, outdated, or inappropriate items in lists of grouped information by having information presented simply and in a well-organized manner.

Finally, we provided two use cases for use during summative usability testing to achieve the goal of safety-enhanced design by validating that potential patient safety risks are proactively addressed and/or mitigated, one for the inpatient setting and one for the outpatient setting. These use cases may also prove useful for organizations that tailor aspects of the design during implementation and optimization processes to protect against inadvertently introducing new risks to patients. 


\section{$8 \quad$ References}

${ }^{1}$ Buntin, M., Burke, M., Hoaglin, M., \& Blumenthal, D. (2011). The benefits of health information technology: a review of the recent literature shows predominantly positive results. Health Affairs, 30 (3), 464-471.

${ }^{2}$ Gibbons, M.C., et al. (2009). Impact of consumer health informatics applications. Evidence Report/Technology Assessment, Oct (188), 1-546; and Cebul, R., Love, T., Jain, A.K., \& Hebert, C.J. (2011). Electronic health records and quality of diabetes care. New England Journal of Medicine, 365, 825-833.

${ }^{3}$ Longhurst, C., Parast, L., Sandborg, C., et al. (2010). Decrease in hospital-wide mortality rate after implementation of a commercially sold computerized physician order entry system.

Pediatrics, 126, 14-21.

${ }^{4}$ Institute of Medicine. (2001). Crossing the quality chasm: a new health system for the twentyfirst century. Washington, DC: National Academy Press.

${ }^{5}$ Classen, D.C., et al. (2011). Global trigger tool shows that adverse events in hospitals may be ten times greater than previously measured. Health Affairs, 3(4), 581-589.

${ }^{6}$ Han, Y.Y., Carcillo, J., Venkataraman, S., et al. (2005). Unexpected increased mortality after implementation of a commercially sold computerized physician order entry system. Pediatrics, 116(6), 1506 -1512. Correction in Pediatrics, 117(2), 594.

${ }^{7}$ Horsky J, Kuperman GJ, Patel VL. Comprehensive analysis of a medication dosing error related to CPOE. J Am Med Inform Assoc 2005; 12(4):377-82.

${ }^{8}$ Hruschka, D. J., Schwartz, D., Cobb St. John, D., Picone-Decaro, E., Jenkins, R. A., Carey, J. W. (2004). Reliability in coding open-ended data: Lessons learned from HIV behavioral research. Field Methods, 16, 307-331.

${ }^{9}$ Erlandson, D. A., Harris, E. L., Skipper, B. L., \& Allen, S. D. (1993). Doing naturalistic inquiry. Thousand Oaks, CA: Sage.

${ }^{10}$ Lincoln, Y. S., \& Guba, E. G. (1985). Naturalistic inquiry. Thousand Oaks, CA: Sage.

${ }^{11}$ Charmaz, K. (2006). Constructing grounded theory: A practical guide through qualitative analysis. Thousand Oaks, CA: Sage.

${ }^{12}$ Saldaña, J. (2013). The coding manual for qualitative researchers. Thousand Oaks, CA: Sage.

${ }^{13}$ Saldaña, J. (2013). The coding manual for qualitative researchers. Thousand Oaks, CA: Sage.

${ }^{14}$ Richards, L., \& Morse, J. M. (2007). User's guide for qualitative methods ( $2^{\text {nd }}$ ed). Thousand Oaks, CA: Sage.

${ }^{15}$ Charmaz, K. (2006). Constructing grounded theory: A practical guide through qualitative analysis. Thousand Oaks, CA: Sage.

${ }^{16}$ Saldaña, J. (2013). The coding manual for qualitative researchers. Thousand Oaks, CA: Sage.

${ }^{17}$ Saldaña, J. (2013). The coding manual for qualitative researchers. Thousand Oaks, CA: Sage.

${ }^{18}$ Saldaña, J. (2013). The coding manual for qualitative researchers. Thousand Oaks, CA: Sage.

${ }^{19}$ Lincoln, Y. S., \& Guba, E. G. (1985). Naturalistic inquiry. Thousand Oaks, CA: Sage.

${ }^{20}$ Patton, MQ. (1999). Enhancing the quality and credibility of qualitative analysis. HSR: Health Services Research, 3, 1189-1208. 
${ }^{21}$ Mays, N. \& Pope, C. (2000). Qualtative research in health care: Assessing quality in qualitative research. BMJ: British Medical Journal, 320, 50-52.

${ }^{22}$ Ahlstrom, V., \& Longo, K. (2003). Human Factors Design Standard (HF-STD-001). Atlantic City International Airport, NJ: Federal Aviation Administration William J. Hughes Technical Center.

${ }^{23}$ Svetlana, L.Z., Matthew, Q.T., Ramaiah, M., Schumacher, R.M., Patterson, E.S., North, R., Zhang, J., Gibbons, M.C., Abbott, P. "NISTIR 7804 Technical Evaluation, Testing and Validation of the Usability of Electronic Health Records.” NIST Interagency/Internal Report (NISTIR) 7804, 2012. Available at: http://www.nist.gov/customcf/get_pdf.cfm?pub_id=909701. 